\title{
Nothing Lasts Forever: Environmental Discourses on the Collapse of Past Societies
}

\section{Guy D. Middleton}

\section{Journal of Archaeological Research}

ISSN 1059-0161

Volume 20

Number 3

J Archaeol Res (2012) 20:257-307

DOI 10.1007/s10814-011-9054-1

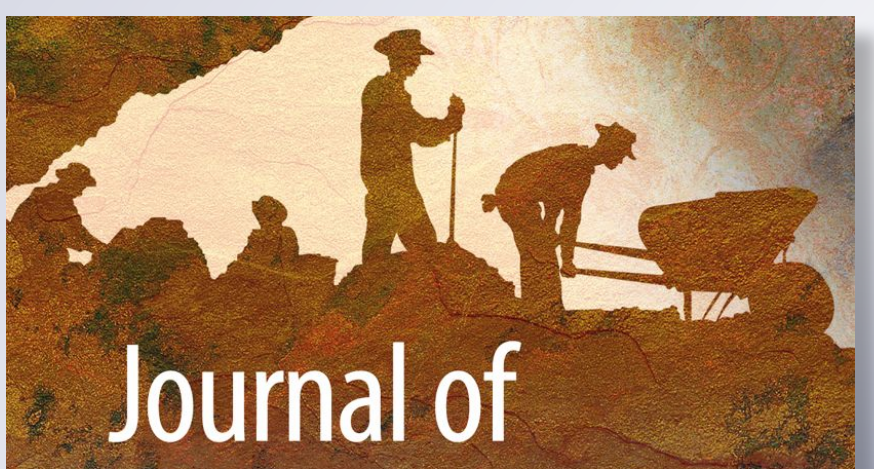

Archaeological Research

Volume 15 Number $1 \cdot$ March 2007

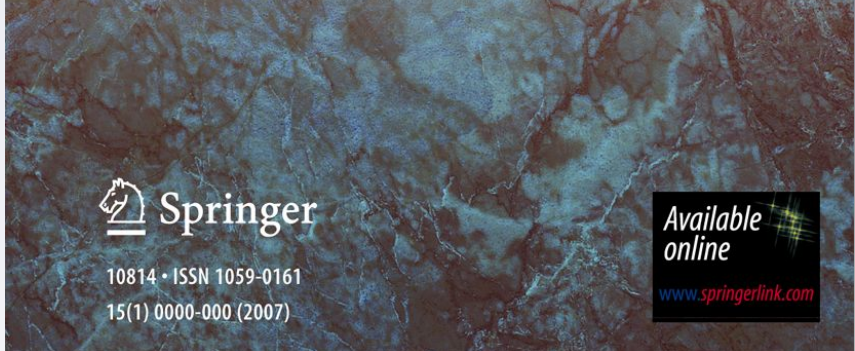


Your article is protected by copyright and all rights are held exclusively by Springer Science+Business Media, LLC. This e-offprint is for personal use only and shall not be selfarchived in electronic repositories. If you wish to self-archive your work, please use the accepted author's version for posting to your own website or your institution's repository. You may further deposit the accepted author's version on a funder's repository at a funder's request, provided it is not made publicly available until 12 months after publication. 


\title{
Nothing Lasts Forever: Environmental Discourses on the Collapse of Past Societies
}

\author{
Guy D. Middleton
}

Published online: 11 January 2012

(C) Springer Science+Business Media, LLC 2011

\begin{abstract}
The study of the collapse of past societies raises many questions for the theory and practice of archaeology. Interest in collapse extends as well into the natural sciences and environmental and sustainability policy. Despite a range of approaches to collapse, the predominant paradigm is environmental collapse, which I argue obscures recognition of the dynamic role of social processes that lie at the heart of human communities. These environmental discourses, together with confusion over terminology and the concepts of collapse, have created widespread aporia about collapse and resulted in the creation of mixed messages about complex historical and social processes.
\end{abstract}

Keywords Collapse $\cdot$ Determinism $\cdot$ Environment $\cdot$ Narrative $\cdot$ Resilience

\section{Introduction}

Scholarly and popular interest in the collapse of societies has produced a vast and multifaceted discourse (Aimers 2007; Anderson and Chase-Dunn 2005; Denning 1999; Lawler 2010; Moyer 2010; Vince 2009; Webster 2006). Collapse is addressed at a number of scales, including the destruction or abandonment of individual sites, the end of archaeological and historical cultures, systems, and empires, and in grand narratives of human history and theories of social change. It is of particular interest to those studying the past because it embodies a range of key issues in the theory and practice of archaeology and history. It offers a way to study and characterize the causes and manner of historical change (structure versus agency), while also being a representation of it. Collapse raises issues of how the past is divided up for study (naming and periodizing), of what constitutes appropriate explanation, description,

G. D. Middleton $(\bowtie)$

University of Tokyo, 3-8-1 Komaba, Meguro-ku, Tokyo 153-8902, Japan

e-mail: gdmiddleton@hotmail.com 
and narrative, of how and by whom the past is used, and who it represents or fails to represent. Like all social sciences, archaeology is embedded within and reflects contemporary cultural, intellectual, political, and social concerns; collapse studies is no different (Fash 1994; Possehl 1997; Preucel and Mrozowski 2010; Silberman 1998).

The study of collapse is a cross-, multi-, and interdisciplinary pursuit not only in archaeology and the social sciences but also in the natural sciences (Costanza et al. $2007 \mathrm{a}, \mathrm{b})$. There are multiple discourses of collapse within and between discrete fields, as well as attempts from different perspectives at more synthetic accounts. All of these generate a great deal of evidence, theory, and narrative, which challenge archaeologists to understand and integrate scientific data on ancient climates and environments into their reconstructions of societal change; it equally requires harder scientists to pay attention to how the past is constructed and reconstructed in the social sciences (Lowe et al. 2009). One clear effect of the increasingly available paleoenvironmental data, alongside contemporary concerns over climate change, human impacts on the environment, and sustainability, has been a return by archaeologists and others to more-or-less deterministic views of change in human societies (Crumley 2007).

These views take three broad forms. The first places climatic change as the primary driver of historical change; the second promotes the view that complex societies tend to degrade and outstrip their landscapes, in effect committing "ecocide." Both positions share a catastrophic approach to collapse, in which the human societies in question are the victims of disastrous demographic and social collapse. The third strand, often incorporated into the first two but sometimes distinct, adopts an approach from catastrophism that natural and geological hazards may result in social change of various kinds.

Although these discourses by no means represent the full range of scholarly opinion on collapse, they are currently highly visible in the literature on numerous ancient societies. They are represented not only in popular books but in archaeological journals (region-specific as well as environmental archaeology), social sciences and sustainability literature, and the journals of harder sciences concerned with Holocene and Quaternary studies, geology, and climate change. They also represent the accepted public face of collapse (Abate 1994; Lewis 2010; Tainter 2008). I suggest that they are paradigmatic in that they are shaping and creating a very particular discourse of collapse as primarily an environmental phenomenon [Trigger 1989, pp. 5-6; Manning (2007, pp. 101-102) also is informative here].

This situation presents problems and opportunities, for it highlights a lack of communication and engagement between specialists and specialisms, as well as a failure to communicate clear messages from academia to the public. As Pyle has noted (1997, p. 60), "while the scientific community has a duty to disseminate results to the wider world, popularists of science have an even greater responsibility to ensure that their message is not only clear, but based on fact or justifiable inference."

One effect of such mixed messages is the reduction of public faith in academic research; even more worrying is the use of what are, in reality, contested narratives of past societal collapse to shape policy (E. U. n.d.; Fraser 2009; Glenn and Gordon 1998; Glenn et al. 2009; The Millennium Project 1997; cf. Fagan 2006). The failure to question a paradigm that situates collapse as primarily an environmental or 
ecological issue and does not consider the role of human culture, contingency, and agency results in a very partial and misleading narrative of human history.

Rather than focusing on collapse, many archaeologists now stress the adaptability and resilience of human communities in the face of environmental change and natural hazards (McAnany and Yoffee 2010a; Santley et al. 2000; Scarborough 2007, 2009). Despite differences of scale and technology between many modern and past societies, archaeologists are recognized as being able to generate data and perspectives on how past societies managed issues of water, land, and other resources, as well as how they coped with and responded to environmental hazards such as drought and climate change (Bawden and Reycraft 2000; Hassan 2002; Leroy et al. 2010; Mitchell 2008). Behaviors traditionally associated with collapse, such as migration, changing strategies of subsistence or resource use, and abandonment of monumentalism or complex administrative regimes, are now viewed by some as adaptive strategies, either socially or environmentally.

The question of whether collapse is a "bad thing" or a "good thing" is still worth asking precisely because answers rely ultimately on imagining the perspectives of the subject (individuals, groups, classes, and narrativized and characterized societies, or periods of time) (Pluciennik 1999). But if resilience and adaptation in some cases result in collapse, and other times mean that collapse did not take place, the matter can easily become confused. In fact, the collapse discourse is typified by confusions arising from the different uses and meanings associated with its terminology and concepts.

The task of identifying, describing, and explaining collapse requires consideration of and sensitivity to the material evidence itself and the processes affecting its production, use, survival, and acquisition. New categories of evidence sometimes appear, as a result of both changing perceptions of what constitutes evidence and the development or refinement of techniques; at the same time existing evidence can be added to and reinterpreted. The material evidence and its interpretations are not static bodies of knowledge. The evidence is interpreted with reference to a number of themes, including human agency and motivation, economic, environmental, social, and political processes, and contingent events. It can be considered at local and wider scales (or systems) and at shorter or longer time scales. Because many of these are dynamic, both as they were and as we theorize them, getting a grip on collapse can be far from straightforward.

My aim in this paper is to provide a selective and critical review of the current environmental discourses in collapse and a point of entry to collapse studies in general. I first examine the language and concepts of collapse and then discuss three environmental approaches to explaining collapse-climate change, ecocide, and catastrophist. These approaches are examined through seven case studies. I offer alternative perspectives and provide final comments on the significance and future of collapse studies.

\section{The language and concepts of collapse}

The terminology of collapse is widely recognized as unclear and problematic; even the existence and utility of collapse as a concept is sometimes called into question 
(Ardren 2005; Lawler 2010; Lincoln 1989; Rose 1999). Collapse is a loose term that collocates with a range of equally problematic words and concepts such as decline, fall, crisis and anxiety, transition, and transformation. It is often regarded as catastrophic in terms of either population loss or cultural change. As Demarest notes (2001, p. 105), it is often the ambiguity over what is meant by the term, as well as what kind of entity it is applied to, that creates many of the problems and disagreements in collapse studies.

Collapse, fall, and units of study

A number of scholars define what they mean by collapse and suggest to what kind of human organizations it may apply. Tainter considers collapse a political process in which there is "a rapid significant loss of an established level of sociopolitical complexity" (Tainter 1988, pp. 4-5). In his view, a sociopolitical entity of any degree of complexity can experience collapse, which is a process of simplification and reduction of parts that occurs over a few decades due to declining returns on complexity (Tainter 1988, p. 38). It is applied to anything from empires, states, chiefdoms, local or regional systems, and even individual sites (Alcock et al. 2001; Anderson 1994, 1996; Friedman 2007; Sinopoli 1994, pp. 168-169; Weiss and Bradley 2001). Schwartz's definition of collapse reflects this application and includes "the fragmentation of states into smaller political entities; the partial abandonment or complete desertion of urban centres, along with the loss or depletion of their centralizing functions; the breakdown of regional economies; and the failure of civilizational ideologies" (Schwartz 2006, p. 5). Renfrew includes the disappearance of elites in his definition, since it is often aspects of the material culture associated with elites that disappears in collapse (Lawler 2010, p. 907).

Cowgill (1988, p. 256) proposed that collapse and fall should not be used to describe the political fragmentation of large states or empires into a number of autonomous political units. The reasoning is that the fragmentation of an empire may not involve loss of complexity in the parts that outlast it; the empire itself no longer exists politically, but the societies involved do not collapse socially. Yet this is precisely how Motyl (2001, p. 4) and many others define or use the term collapse in practice.

Another issue is whether "dynastic" change should be considered collapse (Bronson 1988, p. 197; Lincoln 1989, p. 466). Is dynastic change simply a kind of regime change within a continuing entity (as with the Soviet Union), or does it involve the destruction of a political unit and its replacement (which might nevertheless be made to replicate its predecessor in numerous ways)? Both types of change are found in Chinese, Mesopotamian, and Pharaonic history (Abel 2007; Campbell 2009; Lewis 2007, pp. 51-74; Li 2006; E. Morris 2006; Yoffee 2004, pp. 53-59). Recognition of different kinds of dynastic change allows clearer observation of the "pulsing" between periods of increased unity and fragmentation of competitive independent units that has been identified in a number of ancient systems (Marcus 1998).

Collapse occurs to entities within civilizations, defined as the "cultural tradition in which the state is embedded" (Yoffee 1988b, p. 45). It is necessary to "clearly 
differentiate between state, society and civilization and use the last term in a specifically cultural sense" (Cowgill 1988, p. 256). With the transformation of civilizations visible in changing material culture and practices, there is sometimes a clear, if complex, connection with conquest, colonialism, and contact (Day 2008; Deagan 1996; Gosden 2004; Silliman 2005). Pharaonic Egypt and Mesopotamia were incorporated into a number of supraregional empires in which the value and utility of traditional behaviors that signified their "civilization," especially higherstatus practices, were unlikely not to change (Bowman 1996; Geller 1997; Houston et al. 2003; Rempel and Yoffee 1999; see also Wood 1998; Yoffee 2010).

The transformation of Harappan civilization, too, has been associated with invasion of some kind that led to similar changes, from Indic to Indo-Gangetic traditions, though the old idea of an "Aryan invasion" is discredited (Kenoyer 2005, 2006; Lawler 2008; Possehl 1997). It is still not clear how the Harappan urban societies were organized, or whether they were states or not (Possehl 1998; Smith 2006, p. 116; Thompson 2005). The deurbanization (an indicator of collapse) of some long-lived centers around $1900 \mathrm{BC}$ was followed by more regionalized traditions, but Kenoyer (2006) characterizes the period to c. $1300 \mathrm{BC}$ as one in which there also was a great degree of cultural continuity, as well as the appearance of new traditions, some of which were linked to Harappan ones.

Collapses occurred within Chinese, Greek, Pharaonic, Maya, Mesopotamian, and other cultural traditions without those civilizations disappearing (Cowgill in press-a). Indeed, the past has often been used and manipulated in the generation of new social and political units and identities post-collapse (Bronson 2006). The collapse of palace societies in Late Bronze Age Greece and of Classic Maya states involved the disappearance over time of political units and ideologies. Although particular aspects of material culture and ideology that had been widespread, especially connected to the high elites, did disappear, and there were changes in population levels and settlement distribution, neither Maya nor Mycenaean civilization or people disappeared. The western Roman Empire collapsed as a political unit in the 5th century $\mathrm{AD}$, yet what we could term "Roman civilization" was partly adopted by new elites and continued its ongoing transformation within newly autonomous but still interconnected regions that shared some form of Roman heritage (Sarris 2009; Wickham 2009).

Broader cultural transformations were of course influenced by changing political situations, as collapse often involved shifts in the social and political capital of cultural symbols. Collapse both reflects and drives visible change through the medium of social reproduction in changing contexts. In this sense, what we see as collapse is a reflection of social and political realignments (Eisenstadt 1988). Political entities, civilizations, and material culture are interrelated, but it is political entities that collapse.

\section{A demographic disaster?}

Confusion over what collapsed, as well as the visible changes in material culture, shifting settlement patterns, and destructions and/or abandonments associated with collapse, has led at times to the incorrect assumption that widespread depopulation, 
often followed by some kind of sparsely populated dark age, is a typical feature of collapses. As McAnany and Yoffee noted (2010c) in a recent letter to Nature, "the conflation of profound societal change with the notion of biological extinction is a persistent error that runs through much 'collapse' scholarship."

One reason for this is the association of collapse with sudden catastrophic population declines or extinctions in the biological sciences and ecology (Scheffer et al. 2001; Van Englesdorp et al. 2009; Washington-Allen et al. 2009). Another is the widespread depopulation association with colonialist ventures in the Americas, Australia, and the Pacific, which destroyed specific sociopolitical entities on a number of scales and led to the profound transformation of local cultures (Palka 2009; Silliman 2005). Such depopulation is often linked directly with the introduction of new diseases, but other less direct effects of disease and other colonialist processes also were at work (Kirch and Rallu 2007; Lovell 1994; Peiser 2005; Thornton 1997). Ecological and biological usages of collapse, as well as violent and apocalyptic images of historical change and transformation, and colonialist narratives themselves (Van Dommelen 1997), influence such perceptions of collapse.

Overshoot explanations of collapse also focus on depopulation and Malthusian disaster (Culbert 1973, 1988; Redman 2004). In these explanations a growing population becomes unable to support itself in its environment and undergoes sudden catastrophic demographic and social collapse. This is sometimes seen primarily as a result of initially successful environmental adaptations that eventually resulted in overpopulation and carrying capacity being surpassed. Sometimes anthropogenic environmental damage, abrupt climate change, or other proximate causes are cited as stress factors that can cause demographic collapse when a system is under pressure and has become less resilient.

The view that overshoot explains collapse in general, and a number of collapses in particular, has been soundly critiqued (Tainter 2006a; for Ur III see Adams 1988; Michalowski 2008; Pollock 1999; Stone 2002; Thompson 2004; Van de Mieroop 2007; Weiss 2000; Yoffee 1988b, 2004, 2010). In many cases the demographic reconstructions on which such narratives are based are widely divergent (Chamberlain 2006; Hassan 1999).

The use of "cultural collapse" to indicate what is really demographic collapse or depopulation (Chamberlain 2006, pp. 184-185) or the collapse of an empire (Khadkikar et al. 2004, p. 52) conflates very different ideas. Diamond's broad definition seems to incorporate this view of collapse as "a drastic decrease in human population size and/or political/economic/social complexity, over a considerable area, for an extended time" (Diamond 2005, p. 3). But the strict emphasis on population is not applicable to many well-known examples of collapse (McNeill 2010).

Reductions in population connected with collapse do often appear in the archaeological record even if collapse itself is not primarily a demographic phenomenon. Yet the contemporaneity of habitation sites, the time scale of any decline, potential changes to the visibility and patterns of habitation and subsistence, and issues of site formation, preservation, and identification need to be considered (Lewit 2009, p. 79; Stone 2002). 
Decline and fall, or transition and transformation?

The word decline often is applied to populations and numbers of sites, where it simply means a reduction. It also refers to reduced military or economic power (Motyl 2001). When associated with collapse, however, it has a range of vague and subjective meanings associated with anxiety, crisis, decay, decadence, difficulties, failings, loss of ability, and moral or aesthetic judgments about aspects of a culture (Tainter 1988, pp. 74-86; Yoffee 1988a, p. 14). A long-standing discourse in Western culture since before classical times also loads the term (Herman 1997).

Decline should not in itself indicate the end of something, as collapse and fall do. Tainter states that "losses that are less severe, or take longer to occur, are to be considered cases of weakness and decline" (Tainter 1988, p. 4). Diamond suggests that collapse is an "extreme form of several milder forms of decline," in which "it becomes arbitrary to decide how drastic the decline must be before it qualifies to be labelled as a collapse" (Diamond 2005, p. 3). Turchin claims that "historical empires themselves, as often as not, were in the state of decline or even disintegration" (Turchin 2006, p. 4). Here it may be more appropriate simply to recognize ancient states and empires as less permanent and less strongly integrated units that were not unlikely to come apart.

Already in the work of Ibn Khaldun (2005, p. xii), dynastic collapse was preceded by decline. As Bronson observes, "the symptoms of decline are rarely easy to recognize, in spite of the folklore that tells us that things get worse as the end approaches" (Bronson 1988, p. 198); supposed indicators of decline can be identified in societies that do not go on to collapse. Narratives in which the Western Zhou experienced a loss of power between 934 and 771 BC, when the dynasty ended in military defeat, are a case in point.

Li (2006, p. 194), for example, recently attributed the collapse of the dynasty to a contingent explanation, the effects of a particular military strategy adopted by the last king, and suggested that the dynasty could have survived longer if it had not adopted the strategy in question. But he places this event in the context of decline, "at a fundamental level, the fall was the result of the long process of Zhou's gradual weakening" (Li 2006, p. 232). Shaughnessy gives a different perspective, concluding that the year $771 \mathrm{BC}$ would have seemed little different from the years either side of it. Rather than an "unremitting series of crises" (Shaughnessy 1999, p. 351), he emphasized that the Western Zhou period was important as the era in which much that underpinned later Chinese history was created or reinforced.

In other instances of collapse-Harappa, Late Bronze Age Greece, the western Roman Empire, and Teotihuacan - there are similar debates about whether collapse was preceded by some form of decline that caused or allowed collapse to take place, or whether no decline was necessary and collapse took place under contingent circumstances (Cowgill 1997, p. 156; Dickinson 2006a, pp. 41-43; Goldsworthy 2009, pp. 139-153, 405; Lahiri 2000; Possehl 1997, p. 463; Wright 2010, pp. 320-324).

The polarization between contingency and process is misleading though, since both clearly affect the trajectories of human history. Assuming that collapse must be preceded by decline, anxiety, or crisis influences interpretations of evidence to fit 
that narrative. While decline of various sorts may be real, the implications of the term and the way such decline is identified should be made explicit.

Terms now more commonly used, such as transition, change, or transformation, are more neutral, especially when applied to civilizations (Ward-Perkins 2005, pp. 4-5); they are used with this intention in Demarest et al. (2004a) to discuss Maya archaeology. The world of late antiquity, too, is identified as "world in transition," not in "decline from some previously lofty standard" (Bowersock 1988, p. 170; see also Ando 2008; Bowersock 1996; Bowes and Gutteridge 2005; Lewit 2003, 2009). However, these can be equally controversial and value laden. WardPerkins criticizes an EU-funded project on "The Transformation of the Roman World" (Pohl 1997), since "there is no hint here of 'decline,' 'fall,' or 'crisis,' nor even of any kind of 'end' to the Roman world" (Ward 2005, p. 4). Transformation suggests that Rome lived on, but it gradually metamorphosed into a different and not necessarily inferior form. Others also emphasize what they see as reduced standards that people would have experienced, while according the period in question no lesser historical value (Liebeschuetz 2003; Loseby 2000).

Collapse as a lived event and a constructed narrative

Ward-Perkins reminds us that the words we use both signify the historical experience of individuals and relate historical reconstructions and narratives on a number of scales. The word "transition" may mask the real horrors experienced by people during particular historical events and changes, even as it successfully describes changes in political, social, and material culture. Equally, terms such as "anxiety" or "crisis," used to characterize periods, may fail to communicate the active and positive engagement of people with events and circumstances they experience. At the level of archaeological or historical narrative, writers must consider who and what their words represent, and to whom (McGuire 1992; McGuire and Walker 1999; Ren 2006; Rubertone 2000; Wilcox 2010; Wilk 1985).

These caveats also apply to the word "catastrophe," used by Drews (1993) to describe collapses in Late Bronze Age Greece and the eastern Mediterranean around 1200 BC. Drews concluded that this collapse was "for those who experienced it, a calamity," and that it was "arguably the worst disaster in ancient history" (Drews 1993, p. 3). Warfare, violence, relocation and resultant trauma from dislocation are noted as features of many collapses, including in Late Bronze Age Greece and the eastern Mediterranean (Bryce 2005a, pp. 329-340, 2005b; Dickinson 2006a, pp. 55-56; Matthews 2004), the Petexbatun in the southern Maya lowlands (Demarest 2004, p. 255), Cahokia (Pauketat 2004, pp. 151-159), the Four Corners region of the southwestern US (Plog 2008, pp. 146-151), and Wari and Tiwanaku (Janusek 2008, pp. 291-292, 294-296).

Catastrophe indicates sudden and severe change; in this sense it is related to the geological catastrophism associated with Cuvier, who suggested that extinctions in the fossil record were caused by periodic catastrophic geological events (Hallam 2004, pp. 8-11). Catastrophism is again present in geology and biology, for example, in the punctuated equilibrium hypothesis of species change and ecosystems shifts (Scheffer et al. 2001). The current recognition of the dynamism 
and instability of the global environment may also encourage a more general application of catastrophist thinking to both the history of the human species and social history (King and Bailey 2006).

Even though the political fragmentation of an empire could be relatively peaceful (Lincoln 1989, p. 461), the shifting capital and utility of certain identities and practices also could result in less obvious kinds of tension and trauma. The diverse fates of Anglo-Indians, an identity group created as a by-product of imperialism within a specific sociohistorical context, during and after Indian independence and partition, provide interesting examples (Blunt 2003; Caplan 2001; McMenamin 2006). Herodotus (1996, pp. 65-67, 462-463) vividly portrays peoples' feelings about the physical abandonment of Greek poleis and their ancestral lands, even though it was conceivable for these to continue even detached from their physical and geographic origins. When such communities did dissolve, a key foundation of a person's identity disappeared; even if not accompanied by violence, this would surely be potentially "catastrophic."

Characterizations of collapse are often implicitly negative, but some scholars also note that these can be considered times of opportunity and even "good" for some (E. Morris 2006). Joyce et al. (2001) argue that collapse tends to be considered a top-down event and that the role of "commoners" has been little considered and undertheorized. They demonstrate that the agency of commoners played a role in collapse and transition in the Río Verde Valley in Oaxaca. This can be recognized through changes in settlement patterns, selective rejection of aspects of elite material culture and practice, and appropriation of sacred spaces reused in new ways - strategies of engagement, avoidance, and resistance. In Late Bronze Age Greece, too, and even the eastern Mediterranean in general, some suggest that the ending of the palace system created a more egalitarian society that was less repressive or burdensome (Betancourt 2000; Deger-Jalkotzy 1996, 2006, p. 174; Van de Mieroop 2010, pp. 247-249).

\section{Dark ages, resilience, and regeneration}

The period after collapse has traditionally been characterized as a dark age, a term that is at once comparative and negative, long contested and often unfashionable, but still conceptually present in some form (Bell 1971; Hall 2007, pp. 64-65; Hawkins 2009; Lemos 2010). A recent adoption of the term extends its meaning to indicate periods of environmental crisis, regeneration, and social transformations, even suggesting we may currently be living in a dark age (Chew 2001, 2002, 2005; Modelski 2007).

A dark age refers objectively to a period with comparatively few written texts, sites, or pottery; qualitatively it also characterizes a time perceived as less stable, more violent, less civilized (or urban) and less "good," with material culture that is judged inferior to that of other periods. They are often considered as empty of people and comfort. The term was originally applied to the perceived intellectual darkness of post-Roman Western Europe (Mommsen 1942), but it overlaps with terms adopted elsewhere, such as intermediate or warring states period, and hiatus, 
which indicate an interruption of what are often considered in hindsight to be normal or desirable periods of unity, stability, or progress.

Given that human populations rarely disappear completely, "resilience" is now frequently used to stress continuity over collapse, but again the term has been applied with different meanings and implications. Formal resilience theory is grounded in an ecological perspective of episodes of stability and change in humanenvironment relations (Holling 1973; Holling and Gunderson 2002; Redman 2005; Washington-Allen 2009). The relationship is seen as an adaptive cycle in which collapse is associated with periods of increased population and environmental degradation, the "release" phase of the cycle, while reorganization is the " $\alpha$ " phase (Redman 2005, pp. 73, 75). This characterization of the release phase presents it as the result of a maladaptive phase in which downscaling of some kind is forced, resulting in population decrease or dispersal or the abandonment of systems that require high-energy input.

Archaeologists apply this model of long-term adaptive cycles in a variety of cases, including in the southwestern US (Nelson et al. 2006) and Mesoamerica (Scarborough 2009; see also chapters in Redman et al. 2004), but it is unclear whether a shift in terminology from collapse to release, or from dark ages to reorganization, constitutes a conceptual gain. While any human community relies on the carrying capacity of an environment and its environmental threshold, the association of collapse with an overshoot model that is dependent on increasing population and loss of productive potential obscures societies' methods of buffering and displacing environmental impacts to other locations or in transforming limitations through culture (McNeill 2010), primary features of complex societies today and in the past (Tainter 2006b). The circumstances that render a once adaptive system suddenly maladaptive still result in the proximate cause of collapse being the coincidence of contingent situations.

A second use of resilience is more abstract, emphasizing that human individuals and groups adapt to situations through change and response. This is often the case, but again this stance promotes a more strictly biological or ecological view of human populations that undervalues the role and value of culture. Characterization of the process whereby a human population group survives some shock but their culture is profoundly transformed as either collapse or resilience depends on whether the cultural or biological processes are the object of focus.

Schwartz and Nichols and contributors (2006) focus on the re-emergence or regeneration of complex societies as a sequel to collapse and examine the relation of such societies to what preceded them in ideological and institutional terms. Bronson (2006; see also Lewis 1975) usefully defines the way in which people use or discard aspects of the real or imagined past through stimulus or template regeneration. Kealhofer et al. (2009) recently adopted a regeneration approach for the reemergence of complexity at Bogazkoy after the Hittite collapse. This approach places a different value on dark ages as periods of reorganization and activity rather than catastrophe and passivity.

The concept of dark ages does carry an implicit judgment, since they are identified precisely because of the disappearance of certain material features associated with complexity. But Tainter (1999, p. 1025) has observed that since it 
tends to be aspects of elite culture that disappear or become more restricted in collapse, dark ages may have been little different for the majority of people. Morris (1997), too, has emphasized how modern divisions of the past into periods have led to the construction of the Greek dark age (c. 1200-700 BC), and this conclusion must be extended to consideration of other "dark ages."

Is collapse usual or unusual?

McAnany and Yoffee's edited volume (2010a), which stresses the adaptability and resilience of various human communities, is a response to Diamond (2005) and the ecocide school of catastrophic collapse. Its publication sparked a public debate between the editors and Diamond about what collapse is, why it happens, and the degrees and role of human agency (Diamond 2010; McAnany and Yoffee 2010c). It returns us to the question of what researchers consider collapse to be, how it was and is perceived, and the utility of the term.

McAnany and Yoffee and their contributors (2010a) question the view that there have been many instances of collapse qua avoidable catastrophic self-induced environmental disasters. They maintain that " 'collapse' in the sense of the end of a social order and its people" is rare (McAnany and Yoffee 2010b, p. 11). Archaeologists participating in a recent Cambridge conference on collapse came to a similar conclusion (Lawler 2010).

Collapse and demographic collapse should not be conflated, since each can occur mutually exclusively of the other. Yet in seeking to reject the ecocide narrative, McAnany and Yoffee (2010a) at least appear to suggest that collapse almost never happens. Although very specific demographic/social collapse may indeed be rare, collapse as primarily a sociopolitical process involving profound change is not rare but a "process recurrent in history and prehistory" (Liverani 2001, p. 379; Tainter 1988, p. 5).

This mixed message about collapse could be taken to imply that sustainability and environmental change are of no concern because humans as a species tend to be resilient. It is not surprising that some prefer to avoid the term altogether and wonder "why the terms 'collapse' and 'fall' are still used today to describe complex processes of cultural evolution or transformation" (Ardren 2005, p. 225; Rose 1999). Despite these issues, collapse is far from an empty category for the analysis or categorization of social change, even if it is undertheorized (Janusek 2008, p. 209). Collapse is neither a concept in thrall to a view of past societies as static or monolithic nor one that privileges civilization over barbarism-both no longer admissible propositions. Even though it is often possible to identify collapse only in hindsight, the question of whether it went unnoticed "on the ground" presents a false dichotomy between the possible experiences of an individual at the time and that very hindsight that makes the practice of history possible.

Collapse is a term ascribed to a range of processes and events that at their core have rapid or dramatic political and social change. That change has correlates in material culture, whether at the level of the political fragmentation of large empires or the demise of individual polities within a culture zone. It can result in and be a part of the transformation of a culture or signify the end of materially distinct 
communities. The onus is on writers to indicate clearly what they mean by collapse and not to confuse or abandon the concept.

\section{Environmental approaches to the causes of collapse}

Janusek optimistically notes (2008, p. 290) that archaeologists interested in collapse now emphasize the role of human agency and the political, social, and ideological drivers of collapse as opposed to traditional explanations, such as mass migration, or external causes, such as the environment. This is only partly true, however, and does not represent the diversity of discourses within collapse studies. The reality and role of migrations, for example, continue to be an important, if controversial, focus of debate for the c. 1200 BC collapses in the eastern Mediterranean (Yasur-Landau 2010), and in Mesoamerica (Cowgill in press-b). Debate also continues over the potential role in collapse of abrupt or long-term climate change, anthropogenic environmental damage, and catastrophic events. Inevitably, these debates raise issues of agency, choice, and determinism, and challenge researchers to successfully balance event and process-driven interpretations of the past.

Collapse is approached from a number of theoretical perspectives that can and do cycle, falling into and out of fashion (Erickson 1999; Huntington 1915, 1917; Issar and Zohar 2007; Webster 2002, p. 239). Since archaeology is itself a complex system consisting of diverse interlinked communities, this cycling may be asynchronous. What is currently of interest in one subfield may be currently unfashionable in another. Here I discuss under three broad headings (in practice there is overlap; see Reycraft and Bawden 2000, p. 4) those environmental approaches that appear to be highly prominent in current discourses on collapse.

\section{Climate change and neodeterminism}

The resurgence of explanations of collapse and historical change as driven primarily by, or profoundly affected by, long-term or abrupt climatic changes that affected the conditions of subsistence and production is unsurprising given current concerns over climate change and global warming (Abate 1994; Behringer 2010; Christie 2008; Fagan 2008; Fleming 1998; Linden 2007; Manzanilla 1997). The scientific study of paleoclimatology also has revealed the profound dynamism and instability of local, regional, and global climates in the Holocene and has enabled climatic change to be mapped chronologically with a high degree of precision (Alley 2000; Botkin 1990; Dincauze 2000; Kuniholm 1990; Maher et al. 2011; Mayewski et al. 2004). Past climate can no longer be assumed to have been identical to today nor to have remained static, and past climate data require consideration and integration into reconstructions of the past (Bryson 1994; Fagan 2004). In fact, paleoclimatic studies have already profoundly impacted the study of collapse and culture change, and a new determinism is in evidence.

A number of recent publications by archaeologists, historians, climate scientists, and others see climate as stimulating societal change, both collapse and increasing complexity, in a number of past societies (Benson and Berry 2009; Benson et al. 
2007, 2009; Brooks 2006; Burroughs 2005, pp. 188-193, 250-260; Charles et al. 2010; deMenocal 2001; Kennet and Kennet 2006; Madella and Fuller 2006; Orlove 2005; Richer et al. 2001; Tsonis et al. 2010; Zhang et al. 2005, 2006, 2007a, b). For some, climate has again become the main driver in human history, "since all human cultures were, and still are, products of their environment" (Issar and Zohar 2007, p. xxvi). Catto and Catto (2004) emphasize the role of climate, even while raising the question of climate change as a "driving force, supporting player, or background noise." Leroy too suggests that it is right to "resurrect environmental determinism" (Leroy 2006, p. 7). Some archaeologists find this position more defensible in light of numerous apparent coincidences between climatic events and cultural change (Allen 2010; Schiettecatte 2010; Wright 1993).

If archaeologists and historians have sometimes been blamed for a failure to engage with scientific evidence (Issar and Zohar 2007, p. xxv; Kuniholm 1990), it is equally unfortunate that there is also a lack of engagement with ongoing archaeological and historical research and theory from researchers outside these fields. The views of archaeological or historical specialists are sometimes misrepresented or even ignored by specialists in other fields (e.g., Mayewski et al. 2004, p. 252, make no mention of Webster 2002).

Some accounts also perpetuate ideas that are discredited or controversial in archaeological and historical explanations of change, such as simplistic notions of climate-driven mass migrations that often hark back to origin myths and other hardto-interpret accounts (Behringer 2010, p. 56; Burroughs 2005, p. 258; Neumann 1993; Neumann and Parpola 1987; but see Drews 2000; Hall 1997). Nonarchaeologists, who are perhaps unfamiliar with the contested nature of archaeology, often misunderstand the dynamic nature of archaeological or historical "facts," in which the event being explained may change or disappear when new evidence appears, or when existing evidence is reconsidered or reinterpreted in different ways. Nevertheless, there has been and continues to be engagement on both "sides" (Buckley et al. 2010; Büntgen et al. 2011; Roberts et al. 2011).

Maher et al. (2011), in their analysis of the role of abrupt climate change in prehistoric cultural change in the southern Levant, highlight a number of germane issues that apply generally to this approach. They stress the need for high-resolution chronological data and note that some episodes of culture change appear to precede the climate changes with which they had been associated (Maher et al. 2011, pp. 9, 18). Such evidence can be difficult to acquire (Manning 2006-2007). They also note that given the varied topography of local areas, global climatic changes would have had differing effects on regional, local, and microscales (Maher et al. 2011, p. 20). The consequences of such shifts on ecosystems are likely to be more complex and less obvious than generally considered (Scheffer et al. 2001). In addition to these problems, Maher et al. (2011, p. 22) suggest that we also question the cultural models under consideration, as they can lump together artifact types, settlement patterns, and chronological periods.

Coombes and Barber (2005) have suggested that human societies, as complex self-organizing systems themselves, react to instances of "forcing" in nonlinear ways: forcing factors of different kinds could result unpredictably in collapse, or not. In addition to understanding what changes actually took place climatically and 
then ecologically, and what the human responses were immediately and over time, the scientific evidence itself also needs to be understood and evaluated. The question of the extent to which small data sets that may be global or regional in origin can be meaningfully applied to the explanation of specific local cases of culture needs to be asked (Kuniholm 1990), and the processes that lead to the formation of such evidence within their particular macro- and microenvironments, as well as its final interpretation, must be considered (Town et al. 2008). While none would deny the relationship of human communities to the climate and environment, the question of balancing evidence and causality in interpretation remains problematic. Many archaeologists would agree with Maher et al. that "current evidence (radiocarbon, paleoclimatic and archaeological) does not support simple cause-and-effect relationships between rapid climate-change events and cultural changes" (Maher et al. 2011, p. 3).

\section{Ecocide and maladaptation}

The place of humanity as an interdependent part of environmental systems, though not new, has been seen as increasingly relevant to studies of the past and to current concerns over sustainable practices (Butzer 1982; Costanza et al. 2007a, b; Dincauze 2000, pp. 5-6; Hornborg and Crumley 2007; Redman 1999). The often complex and reciprocal impacts of human cultures and their sustaining environments also are apparent (Dearing 2006; Evans 2003; Hayashida 2005; Kirch 2005; Redman et al. 2004; Williams 2000). These developments have grown up in concert with environmental and conservation movements from the 1960s onwards, resulting in what Trigger (1989, pp. 319-326) terms cataclysmic archaeology. The realization that anthropogenic environmental damage and degradation posed serious issues for sustainability, along with a Malthusian recognition of limits to necessary but finite resources used in industry and the dangers of population growth, has helped create a collapse paradigm for the present.

In some cases, archaeological research demonstrates that human societies can undermine their own environment, resulting in collapse by overshoot (discussed above). A case has been made for this factor in the collapse of Late Bronze Age Greek polities (Runnels 1995, 2000; Wells et al. 1993; see also Bloedow 1995), Chaco (Kohler 1992; Kohler and Matthews 1988; see also Mills 2002, pp. 97-100; Mills 2004; Wills 2009), the Classic Maya (Oglesby et al. 2010; Pringle 2009; see also McNeil et al. 2010), and Mesopotamian Ur III (Jacobsen and Adams 1958; see also Powell 1985). Deforestation and soil erosion in particular play a significant role in this discourse, along with suggestions of increased salinization from irrigation and agricultural intensification (Chew 2001, 2005; Diamond 2005, p. 487; Ponting 2007).

The best-known example of ecocidal collapse is the argument that Rapa Nui (Easter Island) society "self-destructed" in a Malthusian demographic and cultural disaster. Bahn and Flenley (1992) popularized this narrative and the notion that Rapa Nui was a valid analogy for an Earth under pressure. This case is discussed further below. Now it is Diamond's recent volume (2005) that represents the wellknown face of this paradigm (see also Good and Reuveny 2009; Janssen and 
Scheffer 2004), but it follows in the footsteps of others (Flenley and Bahn 2003; Ponting 2007; Redman 1999).

The ecocide argument tends to present human societies as existing in a form of maladaptation to their surroundings (Rappaport 1977). The ecological extension of this is that collapse enables a periodic environmental and cultural resetting to take place, and then new societies can develop (Chew 2002, 2005). This alternative form of determinism (deterministic because of the cyclical nature of the process) places responsibility for collapse on the inhabitants of past societies themselves rather than on climatic or other external factors; in practice many discussions mix these causes.

Although expressions of this narrative are often motivated by a well-intentioned desire to help humanity avoid collapse in the present and future by educating people about human impacts on the environment and promoting sustainable practices (though see Kirch 1997, p. 39; MacMillan 2010), this use of archaeology, and in particular the presentation of the history of past peoples and societies involved, has provoked heated debate (deMenocal et al. 2005; Lewis 2010; Tainter 2010). Diamond has drawn the brunt of academic criticism, due in part to the success and visibility of his books (Diamond 1997, 2005). Despite nuancing his views (2005, pp. 11-15), the widespread acceptance of how his narrative is taken to characterize collapse and past societies illustrates the potential for continued miscommunication about collapse.

\section{Collapse and neocatastrophism}

Both climate change and ecocide approaches to collapse incorporate various aspects of catastrophist thinking in terms of the abruptness of climate change events, the suddenness of an ecological collapse, and the effects of these on populations and societies. But catastrophism in a stricter sense, the notion that natural hazards can cause the abrupt end of human societies, also has returned to the foreground in explanations of collapse and social change (Ambraseys 2005; Bawden and Reycraft 2000; Leroy et al. 2010; Nur and Burgess 2008). A recent popular volume claims that a massive volcanic eruption in AD 535/536 "blotted out much of the light and heat of the sun for 18 months and resulted, directly or indirectly, in climatic chaos, famine, migration, war and massive political change on virtually every continent" (Keys 2000, p. 1). This hypothesis has been received favorably by at least one scholar (Whitby 2000), though not by others (Saunders 2000). In addition to geological catastrophes, plagues and epidemics also take their place in this literature (Acuna-Soto et al. 2005; Little 2007: Walløe 1999).

The resilience of catastrophe-based explanations is often related to their apparent simplicity and the media coverage given to contemporary catastrophes (Ambraseys 2006, pp. 1011-1012; Leroy 2006, p. 10; Rose 1999). But catastrophes have long formed part of human physical and metaphysical experience, and a catastrophe discourse is found in many human societies past and present (Piccardi and Masse 2007; Svensen 2009, pp. 17-33). There has long been a link between catastrophism and biblical archaeology, for example, since geological events can offer rational explanations for biblical events (Bentor 1989; Nissenbaum 1994; Siverstein 2009). 
Earthquakes, storms, and droughts are the three most significant causes of mortality by natural disaster between 1970 and 2009, with some 88,000 killed and almost 46 million people affected by the 2008 earthquake in China alone (CRED 2010). The 2010 earthquake in Haiti has been held responsible for catastrophic social collapse in that country, attendant though on the conditions of the country when disaster struck (Robertson 2010). The earthquake that struck Bam, Iran, in 2003 documents the physical damage that could be caused to a premodern city and also the aftereffects in terms of health and psychological trauma (Akbari et al. 2004; Montazeri et al. 2005).

Several reasons explain a general prejudice against catastrophic explanations for societal collapse. The first is that no major society has clearly collapsed as a result of such events. The association of catastrophes with myth and "acts of God" also creates suspicion about catastrophes as appropriate or acceptable explanations (Masse et al. 2007). Another point is that archaeologists in more developed nations tend to be well buffered against the worst effects of catastrophes (as indeed they are buffered from climate change and resource degradation [McNeill 2010]) and simply do not experience these events in the same way as those who live in poorer or less stable societies. Finally, there is the apparent simplicity of the catastrophist approach: what possible damage, at least to more complex societies, can single events cause when "complex societies routinely withstand catastrophes without collapsing?" (Tainter 1988, pp. 53-54).

As an explanation of collapse, Rose (1999) suggests that rather than identifying potential catastrophes, specific proof of their occurrence at a particular time is needed, as well as a demonstration of "how precisely it would have ended civilization...it isn't enough to say $\mathrm{x}, \mathrm{y}$, and $\mathrm{z}$ problems existed in a civilization and then a catastrophe pushed everything over the edge." Clearly, catastrophes can cause collapse in some instances, depending on the scale considered (Greek poleis as opposed to Greek “civilization"). While past and present societies can and do survive catastrophes, it is equally evident that they could affect the production and economies of the affected areas and those linked to them (Leroy et al. 2010). As with Haiti, the social effect of any catastrophe is dependent on a number of other factors and are therefore contingent and not necessarily predictable. Indeed, Leroy (2006, p. 5) notes that the amplitude of a catastrophe is affected by three factors in particular: onset time and duration of the event (time), the area affected in terms of size and use (area), and the type or society and ecosystem affected (type) (see also Reycraft and Bawden 2000). The Bam earthquake killed many because it struck while people were asleep.

Some have attempted to create the kind of narratives required by Rose (1999), though the production of incontrovertible evidence and proof of causality may rarely be possible in a science based on the interpretation of primarily material evidence (Kohl 2008, p. 498). That there are linkages between catastrophes and their effects on society seems uncontroversial (De Boer and Sanders 2002; Nur and Burgess 2008, pp. 246-277). A devastating earthquake that destroyed classical Sparta in $464 \mathrm{BC}$ had the potential to destroy the political state since it facilitated a revolt by the helots; in this case the event provided an opportunity for human action (Hall 2007, p. 286). 
Charisma, ideology, and the perception of community, rather than institutions alone, play a role in binding together some human groups, and catastrophes, as much as other events, affect confidence in leaders or systems. Thus, for leaders who maintained an ideological system based on their successful intervention in providing rain, for example, any reduction in rainfall would reflect on their status and challenge the cohesion of the system (Lucero 2002). Leaders and systems that are considered unsatisfactory today are equally prone to revolution and, in some cases, systemic and ideological changes that may look like collapse to future archaeologists (Sanderson 2005).

Issues of subject, scale, and definition are crucial for considering the role of hazards and catastrophe. Mackil (2004) examined a number of cases of polis collapse that occurred because of physical catastrophe. In Greece, the polis of Helike was destroyed by an earthquake and tsunami in $373 \mathrm{BC}$, completely, according to the literary (but not archaeological) sources, and it ceased to exist as a political unit (Mackil 2004, pp. 498-499). Its former territory was divided among its neighbors. Specific social and political and physical units were abandoned, and people and land that had constituted the lapsed entity were redistributed through processes involving neighboring centers and wider regional social and political networks. Greece did not exist as a political unit, and the polis was the unit of citizenship and identity for most "Greeks" (Hall 2007, pp. 67-92). Neither the wider culture system nor its civilization collapsed because of these events, but that should not be expected. In a microcosm, this is a prime example of the reconstruction of political and social boundaries and identities following a collapse on a particular scale. It also demonstrates how members of one system can become undetectable archaeologically, even though they are not biologically extinct (compare chapters in Higham 2008). Reactions to catastrophic occurrences in other areas provoked similar reactions: both the end of societies and successful adaptations (Chester et al. 2000; Gonzalez et al. 2000; Plunket and Uruñuela 2000).

\section{Case studies}

I now summarize ongoing debates in seven case studies. These examples show how the environmental approaches are applied and contested. They raise questions and issues that apply equally to other cases of collapse.

Climate change and megadrought

\section{Northern Mesopotamia and Syria}

Based on their excavations and survey in and around Tell Leilan in northern Mesopotamia, Weiss and colleagues proposed that widespread urban abandonment and the collapse of the Akkadian empire was caused by increased aridification around 2200-1900 BC, which followed a volcanic eruption that was contemporaneous with an extended dry period (Weiss 1997, 2000; Weiss and Courty 1993; Weiss et al. 1993). Further supporting evidence for this climate event has been 
identified in sediment cores from the Gulf of Oman (Cullen et al. 2000; Staubwasser and Weiss 2006). Weiss and colleagues (1993) argue that these conditions led to desertification and decreased agricultural productivity, especially in the Habur region. This weakened the Akkadian empire, which was economically dependent on the region, and also caused a number of population movements that destabilized other areas of Mesopotamia. They and others associated climate change with other episodes of collapse that occurred around the same time in the Aegean, Egypt, Harappa, and Palestine (deMenocal 2001; Staubwasser and Weiss 2006; Weiss et al. 1993, p. 1002). Weiss and Bradley (2001) later extended the argument to suggest that climate change was in fact the prime cause of societal collapse in general.

Despite the array of evidence and interpretation built up by Weiss and others, their Mesopotamian narrative has not found universal acceptance for a number of reasons (Weiss 1996). Zettler (2003) acknowledged the importance of Weiss' efforts to bring together multiple types of evidence from a range of disciplines but questions Weiss' textual interpretations, the reliability of the absolute chronology, and the central question of Akkadian economic dependence on the Habur region. In terms of historical reconstruction, some note that Weiss fails to consider that the unity imposed by the Akkadian dynasty was itself an anomaly in the usually fragmented political organization of Mesopotamia (Liverani 2001, pp. 377-380; Zettler 2003, p. 24).

Subsequent research has caused Courty to modify her interpretation of the soil data and to raise the dating of the event she identified (Courty 2001). It also shows that the extent of site abandonment in northern Mesopotamia is much less than Weiss and colleagues had supposed and that there was continued settlement at most major urban sites (Kuzucuoglu and Marro 2007; Wossink 2010). Increased resolution of the ceramic chronology also indicates that the timing of changes to urban life, still "urban collapse" in Ur's words, varied across sites and was not as sudden or universal as sometimes presented (Ur 2010, p. 413). The Akkadian collapse seems best understood as a political collapse in which the attempt to create a unified state from competing independent polities was ultimately outweighed by their desire for independence (Roberts et al. 2011; Van de Mieroop 2007, p. 71).

\section{Classic Maya}

Gill and others have developed an argument that explains the Classic Maya collapse (Terminal Classic period c. AD 750-1050) as a demographic collapse in which millions of people died because of agricultural failure caused by a series of unusually severe and prolonged droughts (Gill 2000; Gill et al. 2007; Pringle 2009). These megadrought events are inferred from lake sediment cores from Lake Chichancanab and Punta Laguna in northern Yucatan (Hodell et al. 1995, 2005) and titanium deposition in the Carioco Basin off northern Venezuela (Haug et al. 2003); they have been linked with solar and volcanic activity (Hodell et al. 2001).

Various dates are given for the droughts, with Hodell et al. (2005) identifying an early phase (AD 770-870) and a late phase (AD 920-1100), punctuated by relatively wetter periods. Curtis et al. (2001, p. 50) proposed that droughts occurred in $\mathrm{AD} 585,862,986$, and 1051, and that those of 585 and 862 "coincide with major 
changes in Maya cultural evolution" and with the ninth century collapse. Gill et al. (2007, p. 288) assemble evidence for the dates of proposed drought events connected (between AD 760 and 930) with cultural change and note that the Classic collapse took place in four phases of abandonment (AD 760, 810, 860, and 910). They emphasize that the collapse was unavoidable, catastrophic, and due directly to climatic factors: "There was nothing they could do or could have done.... In the end, the food and water ran out - and they died" (Gill et al. 2007, p. 299).

Many are receptive to the idea that droughts and climate change played a role in Maya culture change and collapse, especially in Quintana Roo (Aimers 2007, p. 348; Hodell et al. 2007; Leyden et al. 1998). But many who suspect that drought was a factor in the collapse in some Classic Maya polities nevertheless reject the megadrought hypothesis for several reasons (McAnany and Negron 2010; Webster 2002, pp. 239-247). One is the problem of creating a single account to explain changes over a wide spatial and chronological area, and from a relatively small sample of very specific evidence. The sediment cores taken to indicate drought are from northern Yucatan, whereas it is the wetter southern lowlands where collapse is most identifiable early on. And the polities of northern Yucatan, closer to where the sediments were actually laid down, did not collapse at the time; rather they experienced "a time of great activity" (Suhler et al. 2004, p. 450) during the Terminal Classic. Their collapses came later, toward the end of the period (A. Andrews 1990; A. Andrews et al. 2003; E. Andrews 1973; Cobos 2004; Demarest 2004, pp. 268-274). McAnany and Negron (2010, p. 155) note a number of inconsistencies between the water supplies of different centers and the timing of their collapse that run counter to the drought hypothesis.

Demarest notes (2004, pp. 257-260) that in Petexbatun, in the wetter southern lowlands, the problems that led to political collapse appeared in the late seventh century; rather than being sudden, they took over a century to play out as endemic warfare between competing sites took over the region. This created conditions of violence and instability in which demographic decline took place through outmigration and subsistence problems. He also notes that local paleoecological and paleopathological evidence does not indicate climatic change, drought, or famine in the region at the time (Demarest 2006; Dunning et al. 1997; Houston and Inomata 2009, pp. 295-302; Wright and White 1996).

Chase and Chase (2006) examine the transition in the southern lowlands into the Postclassic, seeing a new focus on symbolic egalitarianism. Masson et al. (2006) discuss the formation of the Postclassic state of Mayapan, successor of Chichén Itzá, and demonstrate that aspects of the past were actively used or rejected by the people there (see also Andrews 1993; Demarest 2004, pp. 277-293; Masson 1997; Milbraith and Peraza Lope 2003). Maya states continued to exist along with the Spanish until the last was conquered in AD 1697 (Jones 1998).

Rather than thinking of a single Classic Maya collapse, the Terminal Classic period can best be conceptualized as a long period that was experienced in a variety of ways by people of different status at different sites and in different regions (Aimers 2007; Demarest et al. 2004b; Iannone 2005). Unsurprisingly, Maya culture as a whole looked different at the end of this time, punctuated as it was by numerous collapses, and the Classic era political system based on divine kingship 
(Freidel 2008) did not survive. While many sites and systems did collapse, and some areas apparently became widely depopulated, others did not (e.g., Lamanai; Pendergast 1993, p. 18). Some experienced increased population, continued building, and active trade (Masson and Mock 2004). Despite the profundity of some of the events and processes of the Terminal Classic and after, the Maya were resilient both culturally and as a biological population of Mesoamerica.

\section{Tiwanaku}

A similar trend in explanations for the collapse of Tiwanaku has been identified by Erickson (1999), who identified a (re)cycling of environmentally deterministic explanations suggested by Posnansky (1945), Paulson (1976), and most recently by Kolata, Binford, and others (Binford et al. 1997; Kolata 1993; Kolata and Ortloff 1996). In this scenario, Tiwanaku agriculture, which had developed a well-adapted raised field system (Erickson 1992), collapsed due to megadrought; there was a "gradual change in precipitation around AD 950 followed by a precipitous change in moisture content commencing with the post-AD 1000 period" (Kolata 1993, p. 285, 287, 297; see also Chepstow-Lusty et al. 1996). This drought changed the environmental threshold, "defined as climatic extremes that limit[ed] the complexity of cultural development," since the population supported by the successful agricultural adaptation could not be supported in drier conditions (Binford et al. 1997 , p. 235). The collapse involved the abandonment of raised fields, population dispersal, and cultural collapse (Binford et al. 1997, p. 243). The evidence for drought comes from ice cores from the Quelccaya glacier in southern Peru and sediment cores from Lake Titicaca (Binford et al. 1997; Shimada et al. 1991; Thompson et al. 1985). Some researchers even see parallel droughts causing both the Maya and Tiwanaku collapses, comparing data from Lake Chichancanab with cores from the now-filled Andean lake Marcacocha (Chepstow-Lusty et al. 1996).

Drought supposedly affected agricultural capacity in different areas in turn, beginning with coastal communities around AD 850-950, then colonies such as those in the Moquegua Valley, which relied on canal-fed irrigation, and ending in the Tiwanaku heartland (Kolata 1993, pp. 294-295). Deteriorating agricultural output led to the fragmentation of empire and the end of elite statuses; "Tiwanaku's royal dynasty and court life dissolved" and the cities of Tiwanaku and Lukumurta were largely abandoned in the 11th century AD (Kolata 1993, p. 283). Kolata (1993, p. 296) associates the change to a dispersed settlement pattern in the Tiwanaku and Katari Valleys with the disintegration of the organized raised-field agricultural system that he suggests was tied to the elite. Nevertheless, unlike Gill in his megadrought hypothesis for the Classic Maya collapse, Kolata states that "the people of Tiwanaku themselves did not perish en masse" (Kolata 1993, p. 299).

Erickson (1999), Williams (2002), and Calaway (2005) critique the climate change hypothesis for Tiwanaku collapse. Calaway (2005) questions the presentation of inferences from the Quelccaya ice core data as "empirical reality," suggesting that data have been selected to support the drought hypothesis; he offers a different interpretation. In particular, he notes that due to wide fluctuations in precipitation and temperature over both long and short periods, "environmental data 
cannot assume a common mean" and thus smoothing data and finding a mean in order to recognize divergences from it may not be appropriate (Calaway 2005, p. 783). Ice cores themselves may not provide the best proxy for environmental changes over time as has been thought, due to highly localized wind patterns, especially in mountain areas; snow deposition and ablation can vary greatly from actual precipitation, and interpretation of this evidence is complex and uncertain (Calaway 2005, p. 786, citing Francou et al. 2003; Vuille et al. 2003). Isotope analysis is also less clear-cut in interpretation than often suggested (Town et al. 2008). Calaway identifies the problem of resolving chronological issues between paleoclimatologists and archaeologists, the former finding longer time scales more acceptable than the latter. In striving to integrate evidence from both, he sees a danger of creating "a partial empirical reality out of constructed scientific knowledge" (Calaway 2005, pp. 787-788). As a factoid, this becomes the foundation of explanatory models.

Erickson (1999) and Williams (2002) both note chronological problems; both suggest that the identified drought postdated the collapse of Tiwanaku and Wari and its colonies in the Moquegua Valley. Williams sees the early collapse of colonies as resulting from issues of water resource use and control between the two powers, leading eventually to local revolts, with Tiwanaku's Chen Chen being sacked, destroyed, and abandoned before AD 1050 and Wari's Cerro Baul abandoned in the 11th century (see also Owen 2005). Around Lake Titicaca, he suggests, the evidence seems to show no water shortages until the end of the 11th century, but loss of the maize-growing region of Moquegua may have "increased social susceptibility in the Tiwanaku heartland to severe resource stress that the later drought brought forth" (Williams 2002, p. 372). The sustainability of the Wari state too may have been affected by events in the Moquegua Valley. Erickson notes (1999, p. 635) the continuation of raised field agriculture at Koani Pampa and Huatta, around Titicaca.

While Williams (2002, p. 372) sees the collapse as real, he rightly notes that the magnitude of a hazard cannot be straightforwardly equated with its social impact. Erickson questions the very notion of a collapse and suggests that "culture in Lake Titicaca did not 'collapse' after the serious droughts and floods in recent history, nor did it 'collapse' in the post-Tiwanaku time. Pre-Columbian states and urban centres were ephemeral, rising and falling with some regularity..." (Erickson 1999, p. 641).

Kolata et al. (2000) have responded to Erickson's charges of reductionist and deterministic thinking and stress the empirical reality of collapse. This again highlights an ambiguity in the identification of what exactly it is that is collapsing. They point out (Kolata et al. 2000, p. 425) that they never identified, in Erickson's words, "a total cultural collapse, plunging the Lake Titicaca basin into a postTiwanaku 'Dark Ages'” (Erickson 1999, p. 635), nor denied the active adaptive role of people. Kolata (1993, pp. 290-291), in identifying megadrought as "the ultimate threat and proximate cause" of the Tiwanaku state's collapse, also stated that the process must have taken some generations to work out, and "was accompanied by historically specific instances of social competition, conflict and realignments that are unrecorded in the archaeological record."

In the case of Tiwanaku, the issue of collapse has clearly been clouded by different interpretations of what is meant by the word, as well as by interpretations 
of the scientific evidence and its chronological link with events. Janusek (2004, 2008) has proposed an account of Tiwanaku collapse that integrates the apparent environmental changes with the social and political situation and with collapse as a cultural revolution that was a beginning as well as an end. The collapse combined both political fragmentation and the end of a great tradition that included features of elite culture and urbanization over more than a century (Janusek 2004, p. 202). Tiwanaku collapse "was a dynamic process that resulted in a new and equally significant range of practices and ideals" and was embedded in the development of the Tiwanaku state, which exacerbated existing social tensions (Janusek 2004, p. 176). Yet another model of collapse disputes the idea of gradual change. Owen (2005, p. 74) describes an "explosive" collapse of a state "whose major task was to hold itself together."

A number of authors also address the post-collapse period. Sims (2006) discusses the formation of the Tumilaca culture in the Moquegua Valley. Tumilaca pottery themes derive from Tiwanaku styles but without elite symbolism such as the Front Face Deity and Puma Head, while Tiwanaku cemeteries, households, and temples also show systematic destruction. Thus, "collapse appears as the transformation of local Tiwanaku groups into an assertive and independent set of Tumilaca communities whose ethnic identity - although derived from Tiwanaku - was founded in a new and independent political organization" (Sims 2006, p. 131). Zovar (2007) similarly notes that collapse and cultural regeneration are intrinsically connected; he also discusses the importance of population movements and interaction in the formation of new identities and the necessity of considering the causes of collapse as factors that extend into post-collapse scenarios. The Inca state also incorporated elements derived from both Wari and Tiwanaku (McEwan 2006). A comprehensive review of the Late Intermediate period that followed Wari and Tiwanaku collapse is given by Covey (2008).

\section{Ecocide}

\section{Greenland Norse settlements}

The idea of collapse in Greenland is based on the abandonment of the small but long-lived Viking presence in two settlements (Berglund 1986, 2010; Lynnerup 1996). The western settlement appears to have been abandoned near the end of the 14th century, while the eastern settlement existed for a century longer. The ecocide narrative of collapse focuses on the decisions made by the Norse and their choice of Norse patterns of subsistence and land use in a marginal landscape (McGovern et al. 1988), which are suggested to have resulted in a catastrophic and violent end to the eastern settlement (Diamond 2005, pp. 248-276). In addition to land degradation, which would have reduced the subsistence buffer necessary to survive harder years, other factors in the collapse, such as climate change and the failure of the Norse to embrace Inuit adaptations, are usually cited as key (Barlow et al. 1997; Orlove 2005; Redman 1999, pp. 191-194).

Evidence for a violent end to the settlements is, however, yet to be found; possible evidence of death in situ comes from a single farm at Nipaatsoq in the 
western settlement, abandoned in the 14th century, but no bodies were found (Panagiotakopulu et al. 2007). While there is evidence of land degradation from Norse practices, rising sea levels also may have reduced the amount of land available and the viability of the settlements (Berglund 2010, p. 66). Concerning climate change, McGovern notes (1991, p. 94) that more than coincidence is required for it to be a convincing explanation in itself, although if the onset of the slight cooling of the Little Ice Age between AD 1250 and 1300 did make conditions worse (Redman 1999, p. 191), then this too is a contingent factor. Since the Inuit could survive but the Norse did not, this returns us to the central questions of culture, choice, and (mal)adaptation.

The Norse evidently had some contact with the Inuit over a long period, but unsurprisingly they remained oriented to the Norse culture they were part of and identified with (Gulløv 2008). They were not inflexible or incapable of change; they did adapt to their new environment, replacing metal tools with bone and larger animals and buildings with smaller ones (Berglund 2010, pp. 58-61). Why they did not adopt more Inuit ways is due in part to the desire to retain an existing identity, as well as to socialization and the interpretation of the external world through social and cultural values, which determine acceptable ranges of practice (Friedman 2007, p. 104). Given this, it becomes less appropriate to judge success or failure.

It is difficult to consider the Norse settlements on Greenland as a case of societal collapse or indeed as a "failed experiment" (Redman 1999, p. 191) since the Norse presence lasted almost 500 years. Rather, it seems likely that as the small settlements grew unsustainable in the form desired by their inhabitants and as the unstable climate cooled outmigration occurred over time back into the Norse world (Barlow et al. 1997; Berglund 2010; Buckland et al. 1996; Lynnerup 1996; McGovern 1991).

\section{Rapa Nui}

The ecocide narrative of Rapa Nui collapse also identifies a sudden descent into chaos, violence and warfare, and cannibalism caused by overpopulation, deforestation, declining crop yields, and inability to utilize marine resources. Subsistence difficulties and fierce competition brought about sudden depopulation, changing habitation patterns, and sociopolitical change on the island (Diamond 2005, pp. 107-111; Flenley and Bahn 2003).

The ecocide collapse narrative focuses explicitly on the inhabitants' destruction of the island's extensive Jubaea palm forests (Diamond 1995, 2005; Fagan 2008, p. 176; Mieth and Bork 2010; Ponting 2007, p. 5), an idea that stretches back to French explorer La Pérouse, who visited the island for a day in 1786 (Fischer 2005, pp. 71-72). Islanders chopped down the forests to make rollers to transport the many moai and to create agricultural land for an increasing population. This led to soil erosion and declining agricultural output and affected the sources of fresh water on the island. Lack of wood for canoes restricted access to scarce marine food resources; there was no firewood and no chance of leaving the island (Flenley and Bahn 2003, pp. 191-193). Increased competition for limited resources resulted in a "spiral into chaos and cannibalism" (Diamond 1995, p. 63); endemic warfare 
ensued, and there was a population crash, often dated to around AD 1680 (Rainbird 2002, p. 439). People began to inhabit caves for protection from conflict, while mata'a, bladed weapons, became widespread. As with the Norse in Greenland, the ecocide narrative blames islanders for their failure.

Other authors reject this narrative and question the judgment passed on the islanders. Hunter-Anderson (1998) suggests that forest decline was taking place before human settlement took place, whereas Hunt and Lipo (2010; Hunt 2007) stress the role of rats on impeding forest regeneration (see also Mann et al. 2008; Mieth and Bork 2010; Rainbird 2002). Climate change also has been identified as a cause of deforestation (Nunn 2000; Nunn et al. 2007), although the association of an AD 1300 climate event with changes in cooking around AD 1650 and other events culminating some three centuries later seems a stretch (Hunt 2007; Mieth and Bork 2010); the AD 1300 event itself remains hypothetical (Allen 2006, p. 527). Longterm survival of many species of plants and animals suggests that climate change itself may have had little effect on the island's ecology (Diamond 2005, p. 114), but this depends on the specific characteristics of the paleoenvironment. It seems that some tree species survived into the 20th century (Anderson 2002, p. 383). A recent review, in fact, questions the long-standing interpretations of paleoenvironmental evidence taken to suggest that Rapa Nui was a forested island when settled and suggests that a number of reconstructions are possible (Rull et al. 2010). In any case, ecological changes appear to have taken place over several centuries, with islanders adapting to them (Rainbird 2002).

While ecological, political, and cultural changes occurred on Rapa Nui, demonstrated by an apparent shift from moai construction and erection to toppling, they have been tied by some to the period of European contact rather than earlier (Fischer 2005; Hunt 2007; Hunt and Lipo 2010; Rainbird 2002). Anderson (2002, p. 382) also suggests that statue toppling was practiced throughout Rapa Nui history, with widespread toppling in the late 18th century. No moai were reported as toppled by Roggeveen in 1722 or de Haedo in 1770, but Cook in 1774 reported fallen statues, and none were standing by the 1860s (Fischer 2005, pp. 64-66). Evidently, these changes played out over a long period as groups on the island continued to compete with each other. Although new moai were not constructed, presumably because of the lack of tress, the toppling shows their continued cultural relevance into the contact period. In terms of subsistence, Rapa Nui's productivity was observed by Roggeveen and others (Peiser 2005, pp. 520-521), although the island may have suffered periodic shortages. Whether cannibalism was ever really practiced is uncertain; there is no positive archaeological evidence for it and no evidence that it became a subsistence practice (Fischer 2005, p. 55; Flenley and Bahn 2003, p. 156). Driftwood certainly was valued, and islanders used it to construct canoes; bundles of reeds were also used to create floats (Fischer 2005, pp. 47-49).

The notion that there was a drastic population collapse related to environmental collapse assumes that the Rapa Nui population increased to unsustainable levels that made the society vulnerable to stress (Hunt 2007; Hunt and Lipo 2010; Peiser 2005). Diamond (1995) thought a population maximum of up to 20,000 was not unreasonable but noted estimates of 6,000-30,000 (Diamond 2005, p. 90). Fagan (2008, p. 176) suggested a possible peak population of 15,000 in AD 1600, which 
collapsed during the 1700 s, whereas Fischer (2005, p. 45) suggested 12,000 in the 14 th or 15th century, which halved before European contact. Hunt and Lipo (2010, pp. 38-39) and Peiser (2005, p. 532) emphasize that such numbers are largely guesswork and that the number of habitation sites declined only after European contact.

Anderson notes (2002, p. 383) that warfare was common on Polynesian islands and does not indicate demographic collapse. Evidence for massive population decline is only securely situated in the contact era of the 18th and 19th centuries in connection with introduced diseases and blackbirding (Hunt and Lipo 2010; Peiser 2005; Rainbird 2002). Fischer states that it was between 1862 and 1871 that $94 \%$ of the surviving population either perished or emigrated, and that "in blood and anguish... ancient Easter Island crumbled..." (Fischer 2005, p. 86). In surviving to the present, the Rapa Nui have shown remarkable resilience, mainly in the face of contact with outsiders.

The case of Rapa Nui is one of the best-known examples of supposed collapse by overshoot; it is a key component in a number of narratives that have an explicitly moralizing tone and that seek to condemn unsustainable or environmentally damaging practices in the contemporary world (Bahn and Flenley 1992; Diamond 1995, 2005, pp. 79-119; Ponting 2007, pp. 1-7; Redman 1999, pp. 7-11). As Peiser remarks, "[it] is the poster child of a new environmentalist historiography" (Peiser 2005, p. 513). But this example and that of the Greenland Norse are not, in fact, clear cases of collapse. The use of a version of Rapa Nui history that emphasizes the islanders" "failure," based on fragments of evidence constructed to a modern paradigm rather than the realities of the contact period, seems to be another theft of history (Goody 2006).

Catastrophism

\section{Palatial (Minoan) Crete}

Collapse at the end of the Neopalatial period_-defined as Middle Minoan III until the end of Late Minoan IB, perhaps some 250 years to c. 1450 BC (but see Bruins 2010; Dickinson in press; Manning 2010; Manning et al. 2006; Ramsey et al. 2010) - is identified by the end of a palace-based culture that used Linear A script and the integrated islandwide system that had developed over time (Davis 2008; Manning 2008; Schoep 2010; Tomkins and Schoep 2010), perhaps with some form of Knossian pre-eminence (Bevan 2010). This was accompanied by widespread but selective destruction by fire, abandonments, deurbanization, and possible depopulation (Hallager 2010, p. 153).

Two long-standing hypotheses associate the collapse of Neopalatial society on Crete with the eruption of Thera. Marinatos (1939) saw the eruption itself as destroying the palaces, but it later became clear during excavation of Thera that this was not possible since the eruption took place perhaps some 30-50 years earlier, in LM 1A (Keller 1980; Pichler and Schiering 1977). Other arguments associate the eruption and its possible effects-earthquakes, ashfall, and tsunamis-with the collapse (Antonopoulos 1992; de Boer and Sanders 2002; Luce and Bolton 1976; 
McCoy and Heiken 2000; Monaco and Tortorici 2004). These mechanistic arguments, however, have been doubted and disproved. While Bruins et al. (2008) and others suggested that a tsunami would have destroyed Cretan naval defenses and allowed invasion, purported Mycenaean influence, whatever that is, only becomes more apparent later. Minoura et al. (2000) conclude that tsunami waves, while affecting Aegean and northern Cretan coastlines, would have had little influence on Neopalatial Cretan society. In fact, Bruins et al. (2008) note the rebuilding in fine masonry at Palaikastro, and others emphasize that in LM IB Crete maintained its Aegean and international contacts and regained its prosperity (Davis 2008; Hallager 2010).

Driessen and MacDonald (1997, 2000; Driessen 2001) also doubt that the Thera eruption was the direct cause of the collapse of Minoan Crete in a purely mechanical sense. They, too, argue that there was reconstruction but also that numerous changes in the archaeological record reflect the actual and psychological impacts of the eruption and its effects. Economic dislocation and a loss of faith in the established order based on the palaces are reflected in architectural changes that restricted access and increased local storage facilities (Driessen and MacDonald 2000). They further suggest that existing social tensions would have been exacerbated and that a period of conflict ensued, reflected in the widespread but selective destructions visible in LM $1 B$ and the end of regional Cretan influence.

Although catastrophic explanations tend to be unpopular, and Driessen and MacDonald's narrative is not universally accepted, it does at least benefit from their attempt to integrate and explain archaeological change through reference to demonstrated patterns of social behavior known to occur in response to such events. While avoiding mechanical determinism, it also suggests that collapse may occur for contingent reasons.

This collapse is distinguished from what happened after Late Minoan IB (to LM IIIA2 Early, perhaps around c. 1300 BC). While Tsonis et al. (2010) suggest that climate change prevented Cretans from regenerating their complex society after the Neopalatial collapse, this deterministic view is not borne out by the admittedly confusing picture of Crete after LM IB. It seems that there was a re-emergence of elites at Knossos, which became the only functioning palace, and later at formerly important Neopalatial centers around Crete, although there is little general evidence of administration (Hallager 2010, p. 154; Preston 2008, pp. 316-318). The notion of an organized Mycenaean invasion is now doubted, and an emergent and powerful elite at Knossos can be recognized through its use of Linear B and reuse of some traditional Cretan symbols of power (Driessen and Langohr 2007).

Whether they were a small group of mainland "Mycenaeans" or "Minoans" adopting a new imagery of power oriented to the mainland is unclear; there are mainland elite features in burials combined with Minoan symbols. It is in any case questionable to assign meaningful ethnic identities to groups represented by archaeological assemblages (Preston 2008, p. 316). Although the dating of the Linear B tablets from Knossos and the date of the final destruction of the Knossos palace are disputed (Driessen and Langohr 2007, pp. 179-180; MacDonald 2010), survey reveals very limited evidence for activity during LM IIIB. The site seems to have lost importance in the 13th century BC, not regaining it again until after 1200 
$\mathrm{BC}$ in very different circumstances; power may have been constantly shifting between centers throughout this period (Preston 2008, p. 317). Linear B was used in Chania in LM IIIB, and it may have been a palatial center, but main sites again suffered destruction and abandonment by the end of that period. Widespread settlement redistribution seems to have occurred at the end of LM IIIB (Nowicki 2000; Wallace 2006, 2010).

\section{Late Bronze Age (Mycenaean) Greece}

This collapse is identified by a series of destructions of major centers and palaces, taking place over perhaps a few decades around c. $1200 \mathrm{BC}$, which appear to indicate the end of Mycenaean states (Bennet 2007; Deger-Jalkotzy 2008; Dickinson 2006a, 2010; Middleton 2010). Linear B writing was no longer used and monumental building ceased, among other visible changes particularly related to elite culture (Rutter 1992). Many smaller sites were abandoned, a trend particularly noticeable in Messenia, although there may be problems with the visibility of evidence. Some areas that had not had palace states, such as the northwestern Peloponnese, appear well populated, and some movements of people from palatial areas after $1200 \mathrm{BC}$ is possible, although the nature of such movements is disputed (Iacovou 2008; Middleton 2010, pp. 68-91; Yasur-Landau 2010). Local and overseas trade and contact appear to have continued but on a reduced scale.

A recent trend in explaining the collapse of Late Bronze Age society in Greece, and in the eastern Mediterranean more widely, relies on catastrophic seismic events as a cause. Greece and the eastern Mediterranean are areas of high seismic activity, which has caused periodic destruction throughout history (Stiros and Jones 1996). The use of the earthquake hypothesis to explain collapse is not new; Schaeffer (1948) suggested that Ugarit and other sites were destroyed by seismic activity. The fact that these widespread destructions took place over a multidecadal period was problematic, and his theory was discredited (Nur and Burgess 2008, p. 238). Kilian (1996) also associated earthquakes with changes in material culture at Late Bronze Age Tiryns and extended this to the wider collapse of the Late Bronze Age palace states. At Mycenae, French (1996, 1998, 1999, 2002) accepts that earthquakes periodically affected the site, but she seems more skeptical about the wider effects.

Recently, Nur and colleagues have surveyed archaeological evidence from a wide range of sites and suggest that an earthquake storm-a series of connected earthquakes that can occur over decades-could have caused many of the destructions (Nur 1998; Nur and Burgess 2008; Nur and Cline 2000). A similar but even longer earthquake storm, punctuated by the possibly exceptionally severe AD 365 Crete earthquake, is suspected to have affected Crete and the eastern Mediterranean between the fourth and sixth centuries AD (Stiros 2001; but see Kelly 2004). According to contemporary sources, the AD 365 earthquake destroyed more than one hundred towns on Crete and caused a tsunami that flooded Alexandria and other places (Shaw et al. 2008).

Initially, Nur and Cline (2000, p. 61) were tentative in their claims and held back from assigning all site damage and collapse between c. 1225 and $1175 \mathrm{BC}$ to 
earthquakes. More recently, however, Nur and Burgess (2008) have made a stronger argument for their earthquake storm, but this has been met with some skepticism (Stewart 2008). In his review, Stiros (2009) notes the problem of assigning particular kinds of evidence, such as unburied skeletons and architectural damage, securely to earthquakes, similarly noted by Ambraseys (2005, 2006), who also observed that well-known earthquakes in the eastern Mediterranean seem to have had relatively few long-term social effects.

A number of recent overviews also question why earthquakes at $1200 \mathrm{BC}$ would result in collapse, given that earlier earthquakes had not (Deger-Jalkotzy 2008, p. 391; Dickinson 2006a, p. 46; Drews 1993, pp. 33-47; Shelmerdine 2001, p. 375). French has suggested that "the bureaucratic administration which had been fully stretched to deal with the expansion of the first half of the century followed so soon by a devastating earthquake was not able to cope with another disaster on this scale" (French 2002, p. 135). Thus it was the economic effect of several disasters over time on an already overstretched economy, possibly suffering from reduced trade and a lack of raw materials, that brought about the end of the Mycenae kingdom (French 2002, p. 135). This reinforces the point made by Williams (2002, p. 372) that the link between the magnitude of a natural disaster and its social effects is not clearcut.

Physical destruction then cannot fully explain the collapse of the palace system itself and the rejection of the symbols associated with it. Other explanations emphasize possible increases in regional and local conflict and instability (Dickinson 2006a, pp. 54-56), shifting trade routes or economics (Sherratt 2001, 2003), or a failure of the eastern Mediterranean system as a whole (Bachhuber and Roberts 2009; Betancourt 2000; Bryce 2005a, b; Drews 1993, 2000; Parkinson and Galaty 2009; Popham 1994; Stiebing 1980; Van de Mieroop 2010, pp. 235-253).

Despite popular representations of this collapse as resulting in a "dark age," the Postpalatial period saw the continuity of Mycenaean culture for some century and a half after $1200 \mathrm{BC}$ before a new material culture became widespread. Yet there was more visible regionalism and no indications of complexity to match the regional states of the palatial period (Dickinson 2006b; Eder and Jung 2005; Iakovides 1970; Lemos 2002; I. Morris 2006; Rystedt 1999). Mycenaean society was, in fact, never all "palatial," even before the collapse (Middleton 2010; Tartaron 2010; Wallace 2006).

It is even possible to detect a rich Postpalatial culture, especially phase LH IIIC Middle (Thomatos 2006). At Tiryns there were concerted efforts to reuse the area of the former palace, although the nature of this reuse demonstrates a selective use of the past. These may reflect ideological shifts away from a single ruler to a more oligarchical system (Maran 2001, 2002, 2006). At Mycenae too, French notes (2009) that continued evidence of town planning after c. $1200 \mathrm{BC}$ indicates the presence of some kind of authority and suggests that this authority may have been "palatial" despite the physical changes that lead us to term the period Postpalatial. This is salutary: a continuation of the same authority in a new guise would be difficult to detect archaeologically.

Smaller sites such as Mitrou and Lefkandi in the Euboean Gulf also continue into the Postpalatial period and later and may be important sites for local elites 
(Crielaard 2006; Kramer-Hajos and O’Neill 2008; Sherratt 2006; van de Moortel and Zahou 2005). The northwest Peloponnese and Ionian islands also had a vibrant culture at that time (Eder 2006). Whatever Mycenaean fragments may be found in myth (Sherratt 1990), later Greek society seems to have preserved no clear memory and little heritage from the Mycenaean palaces; rather it had origins in these Early Iron Age cultures (Dickinson 2006b).

\section{Final comments}

This review has demonstrated some of the ways that the language of collapse is used to describe quite different types of change among a number of different units of study. The lack of clarity with which these terms are used often creates confusion and mixed messages about collapse. The language also betrays more or less implicit biases or judgments about what kind of situation might be assumed to be better. I have also considered some of the problems and oversimplifications evident in the way that some apply environmental approaches to explaining collapse.

The view that collapse is a phenomenon simply determined by unexpected environmental or climatic shifts, resource degradation, and maladaptation fails to recognize that reactions to problems and challenges of all kinds are not simple cause and effect; rather they are bound up with and refracted by social realities, priorities, and motivations that may be far from unified or singular. Many collapses may be best seen as representing the consequences of conflicts between and within groups, which led to the materially visible changes that we identify in the archaeological record. Those conflicts may have been triggered or exacerbated by a wide range of both internal and external causes with unpredictable consequences. Whether such times were "good" or "bad" for participants very much depends on the perspective taken; most likely they were both or neither.

This review also shows that any discussion of past collapse must be based ultimately on dynamic bodies of evidence, theory, and interpretation. What seemed like sudden and devastating events to archaeologists some time ago can evidently resolve into more complex and longer-term processes as further research that changes the patterns being explained is undertaken. There is often a desire to weave together a plausible narrative or see new evidence as providing a solution, but interpretation is always subject to questioning and revision. Sometimes it would be better to acknowledge doubt more clearly when there is in fact little evidence, or when it is difficult to interpret or otherwise ambiguous.

Collapse clearly is a lively field for archaeological (and cross-disciplinary) research. Comparison of different cases can be fruitful in that we find similar problems with evidence, chronology, and explanatory discourse. It also shows that episodes of collapse share a connection to the notion of shared ideas and identities at the heart of social groups. This recognition of the fluidity and constant renegotiation of such bonds within the competitive arena of human social systems has led to an increased focus on what happens in the wake of collapse, including the regeneration of complex society that may or may not incorporate elements of previous systems in the construction of new ones (Schwartz and Nichols 2006). 
In many instances of collapse, in Teotihuacan, Tiwanaku, the Classic Maya, Late Bronze Age Greece, and others, the ideological elements of elite cultures are selectively rejected or abandoned and often accompany changes in how people are spread across the landscape. This suggests that many ancient polities were fragile entities that represented attempts at binding together different groups into bigger systems that were prone to collapse (Milner 1990, pp. 29-32; Sherratt 2001). What we see of them materially often represents the parts of systems that served the interests of dominant elites and that were employed to reify their power. Other features that change in collapse, particular settlement patterns and sometimes more dense or higher populations, were probably in some sense dependent on the temporary conditions created by these integrative attempts.

Concern over the sustainability of today's societies and systems in the face of climate change and environmental degradation is one reason to study examples of past collapse and social transformation, but there should be a clear message that these are not usually the sole or simple mechanical causes of such change. At the time of writing, a number of Arab states (Tunisia, Egypt, and Libya) are experiencing revolutionary political change (and in Libya, a mass exodus, food shortages, and humanitarian crises); this is a timely reminder that changing relationships within communities and the dynamic utility and value of social systems as means of mediating interactions themselves cause change. These events can be situated and understood in wider contexts, but equally they have occurred suddenly and unpredictably, and have uncertain long-term consequences.

A rich consideration of sustainability as applied to human communities equates to much more than merely paying attention to climate change, subsistence, or resource concerns, but also to matters of social justice, participation, and exclusion, and must reflect human social interactions that are played out against a dynamic backdrop. As Redman suggests of the Mesopotamian Ur III dynasty: "State ideologies assumed at that time, as do many today, that everyone's interests are served when the interests of central rulers are served. Clearly, however, most people may not share the rulers' objectives and not every segment of society is likely to benefit equally from a particular productive strategy" (Redman 2004, p. 162). The potential social, political, and economic consequences of such situations are plain to see.

Acknowledgments I thank Gary Feinman, George Cowgill, Oliver Dickinson, Linda Nicholas, and the six anonymous reviewers for their constructive criticism and numerous suggestions, all of which have improved this article. I am also grateful to Halvard Buhaug, Mike Charles, Elizabeth French, Mark Geller, Maria Iacovou, Jane Rempel, and Tom Tartaron, who kindly sent me copies of their work, and to Peter Robinson who discussed an early draft.

\section{References cited}

Abate, T. (1994). Climate and the collapse of civilization. Bioscience 44: 516-519.

Abel, T. (2007). Pulsing and cultural evolution in China. In Brown, M. T. (ed.), Emergy Synthesis 4: Theory and Applications of the Emergy Methodology, The Center for Environmental Policy, Gainesville, FL, pp. 37.1-37.18. 
Acuna-Soto, R., Stahle, D. W., Therrell, M. D., Chavez, S. G., and Cleaveland, M. K. (2005). Drought, epidemic disease, and the fall of Classic period cultures in Mesoamerica (AD 750-950): Hemorrhagic fevers as a cause of massive population loss. Medical Hypotheses 65: 405-409.

Adams, R. M. (1988). Contexts of civilizational collapse: A Mesopotamian view. In Yoffee, N., and Cowgill, G. L. (eds.), Collapse of Ancient States and Civilizations, University of Arizona Press, Tucson, pp. 20-43.

Aimers, J. J. (2007). What Maya collapse? Terminal Classic variation in the Maya Lowlands. Journal of Archaeological Research 15: 329-377.

Akbari, M. E., Farshad, A. A., and Asadi-Lari, M. (2004). The devastation of Bam: An overview of health issues 1 month after the earthquake. Public Health 118: 403-408.

Alcock, S. E., D’Altroy, T. N., Morrison, K. D., and Sinopoli, C. M. (eds.) (2001). Empires, Cambridge University Press, Cambridge.

Allen, M. S. (2006). New ideas about Late Holocene climate variability in the central Pacific. Current Anthropology 47: 521-535.

Allen, M. S. (2010). Oscillating climate and socio-political process: The case of the Marquesan chiefdom, Polynesia. Antiquity 84: 86-102.

Alley, R. B. (2000). The Two-Mile Time Machine: Ice Cores, Abrupt Climate Change, and Our Future, Princeton University Press, Princeton, NJ.

Ambraseys, N. N. (2005). Archaeoseismology and neocatastrophism. Seismological Research Letters 76: $560-564$.

Ambraseys, N. N. (2006). Earthquakes and archaeology. Journal of Archaeological Sciences 33: 1008-1016.

Anderson, A. (2002). Faunal collapse, landscape change and settlement history in Remote Oceania. World Archaeology 33: 375-390.

Anderson, D. G. (1994). The Savannah River Chiefdoms: Political Change in the Late Prehistoric Southeast, University of Alabama Press, Tuscaloosa.

Anderson, D. G. (1996). Fluctuations between simple and complex chiefdoms: Cycling in the late prehistoric southwest. In Scarry, J. F. (ed.), Political Structures and Change in the Prehistoric Southeastern United States, University Press of Florida, Gainesville, pp. 231-252.

Anderson, E. N., and Chase-Dunn, C. (2005). The rise and fall of great powers. In Chase-Dunn, C., and Anderson, E. N. (eds.), The Historical Evolution of World-Systems, Palgrave Macmillan, New York, pp. $1-19$.

Andrews, A. P. (1990). The fall of Chichen Itza: A preliminary hypothesis. Latin American Antiquity 1: 258-267.

Andrews, A. P. (1993). Late Postclassic Lowland Maya archaeology. Journal of World Prehistory 7: 35-69.

Andrews, A. P., Andrews, E. W., and Castellanos, F. R. (2003). The northern Maya collapse and its aftermath. Ancient Mesoamerica 14: 151-156.

Andrews, E. W. (1973). The development of Maya civilization after the abandonment of the southern cities. In Culbert, T. P. (ed.), The Classic Maya Collapse, University of New Mexico Press, Albuquerque, pp. 243-265.

Ando, C. (2008). Decline, fall, and transformation. Journal of Late Antiquity 1: 31-60.

Antonopoulos, J. (1992). The great Minoan eruption of Thera volcano and the ensuing tsunami on the Greek archipelago. Natural Hazards 5: 153-168.

Ardren, T. (2005). Review of Webster, D., The Fall of the Ancient Maya: Solving the Mystery of the Maya Collapse [2002]. Latin American Antiquity 16: 225-226.

Bachhuber, C., and Roberts, R. G. (eds.) (2009). Forces of Transformation: The End of the Bronze Age in the Mediterranean, Oxbow Books, Oxford.

Bahn, P., and Flenley, J. (1992). Easter Island, Earth Island, Thames and Hudson, London.

Barlow, L. K., Sadler, J. P., Ogilvie, A. E. J., Buckland, P. C., Amorosi, T. Ingimundarson, J. H., Skidmore, P., Dugmore, A. J., and McGovern, T. H. (1997). Interdisciplinary investigations of the end of the Norse Western Settlement in Greenland. The Holocene 7: 489-499.

Bawden, G., and Reycraft, R. M. (eds.) (2000). Environmental Disaster and the Archaeology of Human Response, Anthropological Papers No. 7, Maxwell Museum of Anthropology, Albuquerque, NM.

Behringer, W. (2010). A Cultural History of Climate, Polity Press, London.

Bell, B. (1971). The Dark Ages in ancient history: 1. The first Dark Age in Egypt. American Journal of Archaeology 75: 1-26. 
Bennet, J. (2007). The Aegean Bronze Age. In Morris, I., Saller, R., and Scheidel, W. (eds.), The Cambridge Economic History of the Greco-Roman World, Cambridge University Press, Cambridge, pp. 175-210.

Benson, L. V., and Berry, M. S. (2009). Climate change and cultural response in the prehistoric American Southwest. Kiva 75: 89-119.

Benson, L. V., Petersen, K., and Stein, J. (2007). Anasazi (Pre-Columbian Native American) migrations during the middle-12th and late-13th centuries: Were they drought induced? Climatic Change 83: $187-213$.

Benson, L. V., Pauketat, T. R., and Cook, E. R. (2009). Cahokia's boom and bust in the context of climate change. American Antiquity 74: 467-483.

Bentor, Y. K. (1989). Geological events in the Bible. Terra Nova 1: 326-338.

Berglund, J. (1986). The decline of the Norse settlements in Greenland. Arctic Anthropology 23: 109-135.

Berglund, J. (2010). Did the medieval Norse society in Greenland really fail? In McAnany, P. A., and Yoffee, N. (eds.), Questioning Collapse: Human Resilience, Ecological Vulnerability, and the Aftermath of Empire, Cambridge University Press, Cambridge, pp. 45-70.

Betancourt, P. P. 2000. The Aegean and the origins of the Sea Peoples. In Oren, E. D. (ed.), The Sea Peoples and Their World: A Reassessment, University of Pennsylvania, Philadelphia, pp. 297-303.

Bevan, A. (2010). Political geography and palatial Crete. Journal of Mediterranean Archaeology 23: 27-54.

Binford, M., Kolata, A. L., Brenner, M., Janusek, J., Seddon, M., Abbott, M., and Curtis, J. (1997). Climate variation and the rise and fall of an Andean civilization. Quaternary Research 47: 235-248.

Bloedow, E. F. (1995). Human and environmental interaction in the emergence and decline of Mycenaean state and society. In Laffineur, R., and Niemeier, W-D. (eds.), Politeia: Society and State in the Aegean Bronze Age, Aegaeum 12, University of Liège, Liège, pp. 639-648.

Blunt, A. (2003). Geographies of diaspora and mixed descent: Anglo-Indians in India and Britain. International Journal of Population Geography 9: 281-294.

Botkin, D. (1990). Discordant Harmonies: A New Ecology for the Twenty-First Century, Oxford University Press, Oxford.

Bowersock, G. W. (1988). The dissolution of the Roman Empire. In Yoffee, N., and Cowgill, G. L. (eds.), Collapse of Ancient States and Civilizations, University of Arizona Press, Tucson, pp. 165-175.

Bowersock, G. W. (1996). The vanishing paradigm of the fall of Rome. Bulletin of the American Academy of Arts and Sciences 49: 29-43.

Bowes, K., and Gutteridge, A. (2005). Rethinking the later Roman landscape. Journal of Roman Archaeology 18: 405-413.

Bowman, A. K. (1996). Egypt After the Pharaohs: 332 BC-AD 642 from Alexander to after the Arab Conquest, 2nd paperback ed., British Museum Press, London.

Bronson, B. (1988). The role of barbarians in the fall of states. In Yoffee, N., and Cowgill, G. L. (eds.), Collapse of Ancient States and Civilizations, University of Arizona Press, Tucson, pp. 196-218.

Bronson, B. (2006). Patterns of political regenerations in Southeast and East Asia. In Schwartz, G. M., and Nichols, J. J. (eds.), After Collapse: The Regeneration of Complex Societies, University of Arizona Press, Tucson, pp. 137-143.

Brooks, N. (2006). Cultural responses to aridity in the Middle Holocene and increased social complexity. Quaternary International 151: 29-49.

Bruins, H. J. (2010). Dating Pharaonic Egypt. Science 328: 1489-1490.

Bruins, H. J., MacGillivray, J. A., Synolakis, C. E., Benjamini, C., Keller, J., Kisch, H. J., Klügel, A., and van der Plicht, J. (2008). Geoarchaeological tsunami deposits at Palaikastro (Crete) and the Late Minoan IA eruption of Santorini. Journal of Archaeological Science 35: 191-212.

Bryce, T. (2005a). The Kingdom of the Hittites, new ed., Oxford University Press, Oxford.

Bryce T. (2005b). The last days of Hattusa. Archaeology Odyssey 8(1): 32-41, 51.

Bryson, R. A. (1994). On integrating climatic change and culture change studies. Human Ecology 22: 115-128.

Buckland, P. C., Amorosi, T., Barlow, L. K., Dugmore, A. J., Mayewksi, P. A., McGovern, T. H., Ogilvie, A. E., Sadler, J. P., and Skidmore, P. (1996). Bioarchaeological and climatalogical evidence for the fate of Norse farmers in medieval Greenland. Antiquity 70: 88-96.

Buckley, B. M., Anchukaitis, K. J., Penny, D., Fletcher, R., Cook, E. R., Sano, M., Nam, L. C., Wichienkeeo, A., Minh, T. T., and Hong, T. M. (2010). Climate as a contributing factor in the demise of Angkor, Cambodia. Proceedings of the National Academy of Sciences 107: 6748-6752. 
Büntgen, U., Tegel, W., Nicolussi, K., McCormick, M., Frank, D., Trouet, V., Kaplan, J. O., Herzig, F., Heussner, K-U., Wanner, H., Luterbacher, J., and Esper, J. (2011). 2500 years of European climate variability and human susceptibility. Science 331(6017): 578-582.

Burroughs, W. J. (2005). Climate Change in Prehistory: The End of the Reign of Chaos, Cambridge University Press, Cambridge.

Butzer, K. W. (1982). Archaeology as Human Ecology, Cambridge University Press, Cambridge.

Calaway, M. J. (2005). Ice-cores, sediments, and civilisation collapse: A cautionary tale. Antiquity 79: $778-790$.

Campbell, R. B. (2009). Toward a networks and boundaries approach to early complex polities: The Late Shang case. Current Anthropology 50: 821-848.

Caplan, L. (2001). Children of Colonialism: Anglo-Indians in a Postcolonial World, Berg, Oxford.

Catto, N., and Catto, G. (2004). Climate change, communities, and civilizations: Driving force, supporting player, or background noise? Quaternary International 123-125: 7-10.

Chamberlain, A. T. (2006). Demography in Archaeology, Cambridge University Press, Cambridge.

Charles, M., Pessin, H., and Hald, M. M. (2010). Tolerating change at Late Chalcolithic Tell Brak: Responses of an early urban society to an uncertain climate. Environmental Archaeology 15: $183-198$.

Chase, D. Z., and Chase, A. F. (2006). Framing the Maya collapse: Continuity, discontinuity, method, and practice in the Classic to Postclassic southern Maya lowlands. In Schwartz, G. M., and Nichols, J. J. (eds.), After Collapse: The Regeneration of Complex Societies, University of Arizona Press, Tucson, pp. $168-187$.

Chepstow-Lusty, A. J., Bennett, K. D., Switsur, V. R., and Kendall, A. (1996). 4000 years of human impact and vegetation change in the central Peruvian Andes - with events paralleling the Maya record? Antiquity 70: 824-833.

Chester, D. K., Duncan, A. M., Guest, J. E., Johnston, P. A., and Smolenaars, J. J. (2000). Human response to Etna volcano during the Classical period. In McGuire, W. G., Griffiths, D. R., Hancock, P. L., and Stewart, I. S. (eds.), The Archaeology of Geological Catastrophes, Special Publications 171, Geological Society, London, pp. 179-188.

Chew, S. C. (2001). World Ecological Degradation: Accumulation, Urbanization, and Deforestation, $3000 B C-A D$ 2000. AltaMira, Walnut Creek, CA.

Chew, S. C. (2002). Globalisation, ecological crisis, and dark ages. Global Society 16: 333-356.

Chew, S. C. (2005). From Harappa to Mesopotamia and Egypt to Mycenae: Dark Ages, politicaleconomic declines, and environmental/climatic changes. In Chase-Dunn, C., and Anderson, E. N. (eds.), The Historical Evolution of World-Systems, Palgrave Macmillan, New York, pp. 52-74.

Christie, P. (2008). The Curse of Akkad: Climate Upheavals that Rocked Human History, Annick Press, Toronto.

Cobos, R. (2004). Chichén Itzá: Settlement and hegemony during the Terminal Classic period. In Demarest, A. A., Rice, P. M., and Rice, D. S. (eds.), Terminal Classic in the Maya Lowlands: Collapse, Transition and Transformation, University Press of Colorado, Boulder, pp. 517-544.

Coombes, P., and Barber, K. (2005). Environmental determinism in Holocene research: Causality or coincidence? Area 37: 303-311.

Costanza, R., Graumlich, L. J., and Steffen, W. (2007a). Sustainability or Collapse? An Integrated History and Future of People on Earth, Dahlem University Press and Massachusetts Institute of Technology, Cambridge, MA.

Costanza, R., Graumlich, L., Steffen, W., Crumley, C., Dearing, J., Hibbard, K., Leemans, R., Redman, C., and Schimel, D. (2007b). Sustainability or collapse: What can we learn from integrating the history of humans and the rest of nature? Ambio 36: 522-527.

Courty, M.-A. (2001). Evidence at Tell Brak for the Late ED III/Early Akkadian Air Blast Event (4 kyr BP). In Oates, D., Oates, J., and McDonald, H. (eds.), Excavations at Tell Brak Volume 2: Nagar in the Third Millenium BC, McDonald Institute for Archaeological Research, Cambridge, pp. 367-372.

Covey, R. A. (2008). Multiregional perspectives on the archaeology of the Andes during the Late Intermediate Period (c. AD 1000-1400). Journal of Archaeological Research 16: 287-338.

Cowgill, G. L. (1988). Onward and upward with collapse. In Yoffee, N., and Cowgill, G. L. (eds.), Collapse of Ancient States and Civilizations, University of Arizona Press, Tucson, pp. 244-276.

Cowgill, G. L. (1997). State and society at Teotihuacan, Mexico. Annual Review of Anthropology 26: $129-161$.

Cowgill, G. L. (in press-a). Concepts of collapse and regeneration in human history. In Nichols, D., and Pool, C. (eds.), Oxford Handbook of Mesoamerican Archaeology, Oxford University Press, Oxford. 
Cowgill, G. L. (in press-b). Migrations, disruptions, and identities in the central Mexican Epiclassic. Ancient Mesoamerica.

CRED (2010). Haiti earthquake brief. Centre for Research on the Epidemiology of Disaster, Université catholique de Louvain. Available at: http://www.emdat.be/publications (accessed 9/9/10).

Crielaard, J. P. (2006). Basileis at sea: Elites and external contacts in the Euboean Gulf region from the end of the Bronze Age to the beginning of the Iron Age. In Deger-Jalkotzy, S., and Lemos, I. S. (eds.), Ancient Greece from the Mycenaean Palaces to the Age of Homer, Edinburgh University Press, Edinburgh, pp. 271-297.

Crumley, C. E. (2007). Historical ecology: Integrated thinking at multiple temporal and spatial scales. In Hornborg, A., and Crumley, C. L. (eds.), The World System and the Earth System: Global Socioenvironmental Change and Sustainability Since the Neolithic, Left Coast Press, Walnut Creek, CA, pp. 15-28.

Culbert, T. P. (ed.) (1973). The Classic Maya Collapse, University of New Mexico Press, Albuquerque.

Culbert, T. P. (1988). The collapse of Classic Maya civilization. In Yoffee, N., and Cowgill, G. L. (eds.), Collapse of Ancient States and Civilizations, University of Arizona Press, Tucson, pp. 69-101.

Cullen, H. M., deMenocal, P. B., Hemming, S., Hemming, G., Brown, F. H., Guilderson, T., and Sirocko, F. (2000). Climate change and the collapse of the Akkadian empire: Evidence from the deep sea. Geology 28: 379-382.

Curtis, J. H., Brenner, M., and Hodell, D. A. (2001). Climate change in the circum-Caribbean (Later Pleistocene to present) and implications for regional biogeography. In Woods, C. A., and Sergile, F. E. (eds.), Biogeography of the West Indies: Patterns and Perspectives, 2nd ed., CRC Press, Boca Raton, FL, pp. 35-54.

Day, D. (2008). Conquest: How Societies Overwhelm Others, Oxford University Press, Oxford.

Davis, J. L. (2008). Minoan Crete and the Aegean Islands. In Shelmerdine, C. W. (ed.), The Cambridge Companion to the Aegean Bronze Age, Cambridge University Press, Cambridge, pp. 186-208.

Deagan, K. (1996). Colonial transformation: Euro-American cultural genesis in the early SpanishAmerican colonies. Journal of Anthropological Research 52: 135-160.

Dearing, J. A. (2006). Climate-human-environment interactions: Resolving our past. Climate of the Past Discussions 2: 563-604.

De Boer, J. Z., and Sanders, D. T. (2002). Volcanoes in Human History: The Far Reaching Effects of Major Eruptions, Princeton University Press, Princeton, NJ.

Deger-Jalkotzy, S. (1996). On the negative aspects of the Mycenaean palatial system. In De Miro, E., Godart, L., and Sacconi, A. (eds.), Atti e memorie del secondo Congresso internazionale di micenologia, Roma-Napoli, 14-20 Ottobre 1991, 2: Storia (Incunabula Greca 98), Gruppo editoriale internazionale, Rome, pp. 715-728.

Deger-Jalkotzy, S. (2006). Late Mycenaean warrior tombs. In Deger-Jalkotzy, S., and Lemos, I. S. (eds.), Ancient Greece from the Mycenaean Palaces to the Age of Homer, Edinburgh University Press, Edinburgh, pp. 151-180.

Deger-Jalkotzy, S. (2008). Decline, destruction, aftermath. In Shelmerdine, C. W. (ed.), The Cambridge Companion to the Aegean Bronze Age, Cambridge University Press, Cambridge, pp. 387-415.

Demarest, A. A. (2001). Climatic change and the Maya collapse: The return of catastrophism. Latin American Antiquity 12: 105-107.

Demarest, A. A. (2004). Ancient Maya: The Rise and Fall of a Rainforest Civilization, Cambridge University Press, Cambridge.

Demarest, A. A. (2006). The Petexbatun Regional Archaeological Project: A Multidisciplinary Study of the Maya Collapse, Vanderbilt University Press, Nashville, TN.

Demarest, A. A., Rice, P. M., and Rice, D. S. (eds.) (2004a). Terminal Classic in the Maya Lowlands: Collapse, Transition and Transformation, University Press of Colorado, Boulder.

Demarest, A. A., Rice, P. M., and Rice, D. S. (2004b). The Terminal Classic in the Maya Lowlands: Assessing collapses, terminations, and transformations. In Demarest, A. A., Rice, P. M., and Rice, D. S. (eds.), Terminal Classic in the Maya Lowlands: Collapse, Transition and Transformation, University Press of Colorado, Boulder, pp. 545-572.

deMenocal, P. B. (2001). Cultural responses to climate change during the Late Holocene. Science 292: $667-673$.

deMenocal, P. B., Demeritt, D., Hornborg, A., Kirch, P. V., McElreath, R., and Tainter, J. A. (2005). Perspectives on Diamond's Collapse: How Societies Choose to Fail or Succeed. Current Anthropology 46 (Supplement): S91-S99. 
Denning, K. (1999). Apocalypse past/future: Archaeology and folklore, write large. In Gazin-Schwartz, A., and Holtorf, C. (eds.), Archaeology and Folklore, Routledge, London, pp. 90-105.

Diamond, J. (1995). Easter's end. Discover 9: 62-69.

Diamond, J. (1997). Guns, Germs and Steel: The Fates of Human Societies, W. W. Norton, New York. Diamond, J. (2005). Collapse: How Societies Choose to Fail or Succeed, Penguin, London.

Diamond, J. (2010). Two views of collapse. Nature 463: 880-881.

Dickinson, O. T. (2006a). The Aegean from Bronze Age to Iron Age: Continuity and Change Between the Twelfth and Eighth Centuries, Routledge, London.

Dickinson, O. T. (2006b). The Mycenaean heritage of Early Iron Age Greece. In Deger-Jalkotzy, S., and Lemos, I. S. (eds.), Ancient Greece from the Mycenaean Palaces to the Age of Homer, Edinburgh University Press, Edinburgh, pp. 115-122.

Dickinson, O. T. (2010). The collapse at the end of the Bronze Age. In Cline, E. H. (ed.), The Oxford Handbook of the Bronze Age Aegean, Oxford University Press, Oxford, pp. 483-490.

Dickinson, O. T. (in press). Crete. In Renfrew, C., and Bahn, P. (eds.), Cambridge World Prehistory, Cambridge University Press, Cambridge.

Dincauze, D. F. (2000). Environmental Archaeology: Principles and Practice, Cambridge University Press, Cambridge.

Drews, R. (1993). The End of the Bronze Age: Changes in Warfare and the Catastrophe ca. 1200 BC, Princeton University Press, Princeton, NJ.

Drews, R. (2000). Medinet Habu: Oxcarts, ships and migration theories. Journal of Near Eastern Studies 59: $161-190$.

Driessen, J. (2001). Crisis cults on Minoan Crete. In Laffineur, R., and Hagg, R. (eds.), Potnia: Deities and Religion in the Aegean Bronze Age, Aegaeum 22, University of Liège, Liège, pp. 361-369.

Driessen, J., and Langohr, C. (2007). Rallying "round a "Minoan" past: The legitimation of power at Knossos during the Late Bronze Age. In Galaty, M. L., and Parkinson, W. A. (eds.), Rethinking Mycenaean Palaces II, 2nd ed., Cotsen Institute of Archaeology, University of California, Los Angeles, pp. 178-189.

Driessen, J., and MacDonald, C. F. (1997). The Troubled Island. Minoan Crete Before and After the Santorini Eruption, Aegaeum 17, University of Liège, Liège.

Driessen, J., and MacDonald, C. F. (2000). The eruption of the Santorini volcano and its effects on Minoan Crete. In McGuire, W. G., Griffiths, D. R., Hancock, P. L., and Stewart, I. S. (eds.), The Archaeology of Geological Catastrophes, Special Publications 171, Geological Society, London, pp. 81-93.

Dunning, N. P., Beach, T., and Rue, D. (1997). The palaeoecology and ancient settlement of the Petexbatun reigion, Guatemala. Ancient Mesoamerica 8: 255-266.

Eder, B. (2006). The world of Telemachus: Western Greece 1200-700 BC. In Deger-Jalkotzy, S., and Lemos, I. S. (eds.), Ancient Greece from the Mycenaean Palaces to the Age of Homer, Edinburgh University Press, Edinburgh, pp. 549-579.

Eder, B., and Jung, R. (2005). On the character of social relations between Greece and Italy in the 12th/ 11th century BC. In Laffineur, R., and Greco, E. (eds.), Emporia: Aegeans in the Central and Eastern Mediterranean, Aegaeum 25, University of Liège, Liège, pp. 485-495.

Eisenstadt, S. (1988). Beyond collapse. In Yoffee, N., and Cowgill, G. L. (eds.), Collapse of Ancient States and Civilizations, University of Arizona Press, Tucson, pp. 236-243.

Erickson, C. L. (1992). Prehistoric landscape management in the Andean highlands: Raised field agriculture and its environmental impact. Population and Environment 13: 285-300.

Erickson, C. L. (1999). Neo-environmental determinism and agrarian 'collapse' in Andean prehistory. Antiquity 73: 634-642.

E. U. (n.d.). Five thousand years of water works supporting diverse human societies. Available at: http://ec.europa.eu/research/water-initiative/years_en.html (accessed 1/6/10).

Evans, J. G. (2003). Environmental Archaeology and the Social Order, Routledge, London.

Fagan, B. (2004). The Long Summer: How Climate Changed Civilization, Granta, London.

Fagan, B. (2008). The Great Warming: Climate Change and the Rise and Fall of Civilizations, Bloomsbury, New York.

Fagan, G. G. (2006). Archaeological Fantasies: How Pseudoarchaeology Misrepresents the Past and Misleads the Public, Routledge, London.

Fash, W. L. (1994). Changing perspectives on Maya civilization. Annual Review of Anthropology 23: 181-208. 
Fischer, S. R. (2005). Island at the End of the World: The Turbulent History of Easter Island, Reaktion Books, London.

Fleming, J. R. (1998). Historical Perspectives on Climate Change, Oxford University Press, Oxford.

Flenley, J., and Bahn, P. (2003). The Enigmas of Easter Island, Oxford University Press, Oxford.

Francou, B., Vuille, M., Wagnon, P., Mendoza, J., and Sicart, J-E. (2003). Tropical climate change recorded by a glacier in the central Andes during the last decades of the twentieth century: Chacaltaya, Bolivia, $16^{\circ}$ S. Journal of Geophysical Research D: Atmospheres 108: 4154.

Fraser, E. D. (2009). Economic Crises, Land Use Vulnerabilities, Climate Variability, Food Security and Population Declines: Will History Repeat Itself or Will Our Society Adapt to Climate Change? Centre for Climate Change Economics and Policy Working Paper No. 1. Available at: http://www. cccep.ac.uk/Publications/Working\%20Papers/WorkingPapers.aspx (accessed 18/6/10).

Freidel, D. (2008). Maya divine kingship. In Brisch, N. (ed.). Religion and Power: Divine Kingship in the Ancient World and Beyond, Oriental Institute, University of Chicago, Chicago, pp. 191-206.

French, E. B. (1996). Evidence for an earthquake at Mycenae. In Stiros, S., and Jones, R. E. (eds.), Archaeoseismology, The British School at Athens and Institute of Geology and Mineral Exploration, Athens, pp. 51-54.

French, E. B. (1998). The ups and downs of Mycenae: 1250-1150 BCE. In Gitin, S., Mazar, A., and Stern, E. (eds.), Mediterranean Peoples in Transition: Thirteenth to Early Tenth Centuries BCE, Israel Exploration Society, Jerusalem, pp. 2-5.

French, E. B. (1999). The Post-palatial levels at Mycenae: An update. Bulletin of the Institute of Classical Studies 43: 222-223.

French, E. B. (2002). Mycenae: Agamemnon's Capital, Tempus, Stroud.

French, E. B. (2009). The significance of changes in spatial usage at Mycenae. In Bachhuber, C., and Roberts, R. G. (eds.), Forces of Transformation: The End of the Bronze Age in the Mediterranean, Oxbow Books, Oxford, pp. 108-110.

Friedman, J. (2007). Sustainable unsustainability: Toward a comparative study of hegemonic decline in global systems. In Hornborg, A., and Crumley, C. L. (eds.), The World System and the Earth System: Global Socioenvironmental Change and Sustainability Since the Neolithic, Left Coast Press, Walnut Creek, CA, pp. 91-108.

Geller, M. J. (1997) The last wedge. Zeitschrift für Assyriologie 87: 43-95.

Gill, R. B. (2000). The Great Maya Droughts: Water, Life, and Death, University of New Mexico Press, Albuquerque.

Gill, R. B., Mayewski, P. A., Nyberg, J., Haug, G. H., and Peterson, L. C. (2007). Drought and the Maya collapse. Ancient Mesoamerica 18: 283-302.

Glenn, J. C., and Gordon, T. J. (1998). State of the Future: Issues and Opportunities. American Council for the United Nations University, Washington, DC.

Glenn, J. C., Gordon, T. J., and Florescu, E. (2009). State of the Future. American Council for the United Nations University, Washington, DC.

Goldsworthy, A. (2009). How Rome Fell: Death of a Superpower, Yale University Press, New Haven, CT.

Gonzalez, S., Pastrana, A., Siebe, C., and Duller, G. (2000). Timing of the prehistoric eruption of Xitle volcano and the abandonment of Cuicuilco pyramid, southern Basin of Mexico. In McGuire, W. G., Griffiths, D. R., Hancock, P. L., and Stewart, I. S. (eds.), The Archaeology of Geological Catastrophes, Special Publications 171, Geological Society, London, pp. 205-224.

Good, D. H., and Reuveny, R. (2009). On the collapse of historical civilizations. American Journal of Agricultural Economics 91: 863-879.

Goody, J. (2006). The Theft of History, Cambridge University Press, Cambridge.

Gosden, C. (2004). Archaeology and Colonialism: Cultural Contact from 5000 BC to the Present, Cambridge University Press, Cambridge.

Gulløv, H. C. (2008). The nature of contact between native Greenlanders and Norse. Journal of the North Atlantic 1: 16-24.

Hall, J. M. (1997). Ethnic Identity in Greek Antiquity, Cambridge University Press, Cambridge.

Hall, J. M. (2007). A History of the Archaic Greek World ca.1200-479 BCE, Blackwell, Oxford.

Hallager, E. (2010). Crete. In Cline, E. H. (ed.), The Oxford Handbook of the Bronze Age Aegean, Oxford University Press, Oxford, pp. 149-159.

Hallam, T. (2004). Catastrophes and Lesser Calamities: The Causes of Mass Extinctions, Oxford University Press, Oxford. 
Hassan, F. A. (1999). Population dynamics. In Barker, G. (ed.), Companion Encyclopedia of Archaeology, Routledge, London, pp. 672-713.

Hassan, F. A. (2002). Droughts, Food and Culture: Ecological Change and Food Security in Africa's Later Prehistory, Kluwer, New York.

Haug, G. H., Günther, D., Peterson, L. C., Sigman, D. M., Hughen, K. A., and Aeschlimann, B. (2003). Climate and the collapse of Maya civilization. Science 299: 1731-1735.

Hawkins, J. D. (2009). Cilicia, the Amuq, and Aleppo: New light in a dark age. Near Eastern Archaeology 72: 164-172.

Hayashida, F. M. (2005). Archaeology, ecological history, and conservation. Annual Review of Anthropology 34: 43-65.

Herman, A. (1997). The Idea of Decline in Western History, The Free Press, New York.

Herodotus. (1996). The Histories, rev. ed. (trans. by de Selincourt, A., revised with introduction and notes by Marincola, J. M.), Penguin, London.

Higham, N. (ed.) (2008). Britons in Anglo-Saxon England, Boydell and Brewer, Woodbridge, UK.

Hodell, D. A., Curtis, J. H., and Brenner, M. (1995). Possible role of climate change in the collapse of Classic Maya civilization. Nature 375: 391-394.

Hodell, D. A., Curtis, J. H., Brenner, M., and Guilderson, T. (2001). Solar forcing of drought frequency in the Maya lowlands. Science 292: 1367-1370.

Hodell, D. A., Curtis, J. H., and Brenner, M. (2005). Terminal Classic drought in the northern Maya lowlands inferred from multiple sediment cores in Lake Chichancanab (Mexico). Quaternary Science Reviews 24: 1413-1427.

Hodell, D. A., Brenner, M., and Curtis, J. H. (2007). Climate and cultural history of the northeastern Yucatan peninsula, Quintana Roo, Mexico. Climatic Change 83: 215-240.

Holling, C. S. (1973). Resilience and stability of ecological systems. Annual Review of Ecology and Systematics 4: 1-23.

Holling, C. S., and Gunderson, L. H. (2002). Resilience and adaptive cycles. In Gunderson, L. H., and Holling, C. S. (eds.), Panarchy: Understanding Transformations in Human and Natural Systems, Island Press, Washington, DC, pp. 25-62.

Hornborg, A., and Crumley, C. L. (eds.) (2007). The World System and the Earth System: Global Socioenvironmental Change and Sustainability Since the Neolithic, Left Coast Press, Walnut Creek, CA.

Houston, S. D., and Inomata, T. (2009). The Classic Maya, Cambridge University Press, Cambridge.

Houston, S. D., Baines, J., and Cooper, J. (2003). Last writing: Script obsolescence in Egypt, Mesopotamia, and Mesoamerica. Comparative Studies in Society and History 45: 430-479.

Hunt, T. L. (2007). Rethinking Easter Island's ecological catastrophe. Journal of Archaeological Science 34: 485-502.

Hunt, T. L., and Lipo, C. P. (2010). Ecological catastrophe, collapse, and the myth of 'ecocide' on Rapa Nui (Easter Island). In McAnany, P. A., and Yoffee, N. (eds.), Questioning Collapse: Human Resilience, Ecological Vulnerability, and the Aftermath of Empire, Cambridge University Press, Cambridge, pp. 21-44.

Hunter-Anderson, R. L. (1998). Human vs climatic impacts at Rapa Nui: Did people really cut down all those trees? In Stevenson, C. M., Lee, G., and Morin, F. J. (eds.), Easter Island in Pacific Context: South Seas Symposium, Easter Island Foundation, Santa Barbara, CA, pp. 85-99.

Huntington, E. (1915). Climatic change and agricultural exhaustion as elements in the fall of Rome. Quarterly Journal of Economics 31: 173-208.

Huntington, E. (1917). Civilization and Climate, Yale University Press, New Haven, CT.

Iacovou, M. (2008). Cultural and political configurations in Iron Age Cyprus: The sequel to a protohistoric episode. American Journal of Archaeology 112: 625-657.

Iakovides, S. (1970). Perati to Nekrotafeion, Archaeological Society, Athens.

Iannone, G. (2005). The rise and fall of a Maya petty royal court. Latin American Antiquity 16: 26-44.

Ibn Khaldun (2005). The Muqaddimah: An Introduction to History, trans. by Rosenthal, F., edited and abridged by Dawood, N. J., new introduction by Lawrence, B. B., Princeton University Press, Princeton, NJ.

Isaar, A. S., and Zohar, M. (2007). Climate Change: Environment and History of the Near East, 2nd ed., Springer, New York.

Jacobsen, T., and Adams, R. McC. (1958). Salt and silt in ancient Mesopotamian agriculture. Science 128: $1251-1258$. 
Janssen, M. A., and Scheffer, M. (2004). Overexploitation of renewable resources by ancient societies and the role of sunk-cost effects. Ecology and Society 9: article 6. Available at: http://www. ecologyandsociety.org/vol9/iss1/art6 (accessed 9/9/10).

Janusek, J. W. (2004). Collapse as cultural revolution: Power and identity in the Tiwanaku to Pacajes transition. In Vaughn, K. J., Ogburn, D. E., and Conlee, C. A. (eds), The Foundations of Power in the Prehispanic Andes, Archeological Papers No. 14, American Anthropological Association, Washington, DC, pp. 175-209.

Janusek, J. W. (2008). Ancient Tiwanaku, Cambridge University Press, Cambridge.

Jones, G. D. (1998). The Conquest of the Last Maya Kingdom, Stanford University Press, Stanford, CA. Joyce, A. A., Bustamente, L. A., and Levine, M. N. (2001). Commoner power: A case study from the Classic period collapse on the Oaxaca coast. Journal of Archaeological Method and Theory 8: 343-385.

Kealhofer, L., Grave, P., Genz, H., and Marsh, B. (2009). Post-collapse: The re-emergence of polity in Iron Age Bogazkoy, central Anatolia. Oxford Journal of Archaeology 28: 275-300.

Keller, J. (1980). Did the Santorini eruption destroy the Minoan world? Nature 287: 779.

Kelly, G. (2004). Ammianus and the great tsunami. The Journal of Roman Studies 94: 141-167.

Kennet, D. J., and Kennet, J. P. (2006). Early state formation in southern Mesopotamia: Sea levels, shorelines, and climate change. Journal of Island and Coastal Archaeology 1: 67-99.

Kenoyer, J. M. (2005). Culture change during the late Harappan period at Harappa: New insights on Vedic Aryan issues. In Bryant, E. F., and Patton, L. L. (eds.), The Indo-Aryan Controversy: Evidence and Inference in Indian History, Routledge, London, pp. 21-49.

Kenoyer, J. M. (2006). Cultures and societies of the Indus tradition. In Thapar, R. (ed.), Historical Roots in the Making of 'the Aryan,' National Book Trust, New Delhi, pp. 21-49.

Keys, D. (2000). Catastrophe: An Investigation into the Origins of the Modern World, Arrow, London.

Khadkikar, A. S., Basavaiah, N., Gundurao, T. K., and Rajshekar, C. (2004). Palaeoenvironments around the Harappan port of Lothal, Gujurat, western India. Journal of the Indian Geophysical Union 8: 49-53.

Kilian, K. (1996). Earthquakes and archaeological context. In Stiros, S., and Jones, R. E. (eds.), Archaeoseismology, The British School at Athens and Institute of Geology and Mineral Exploration, Athens, pp. 63-68.

King, G., and Bailey, G. (2006). Tectonics and human evolution. Antiquity 80: 1-22.

Kirch, P. V. (1997). Microcosmic histories: Island perspectives on "global change." American Anthropologist 99: 30-42.

Kirch, P. V. (2005). Archaeology and global change: The Holocene record. Annual Review of Environmental Resources 30: 409-440.

Kirch, P. V., and Rallu, J. L. (eds.) (2007). The Growth and Collapse of Pacific Island Societies: Archaeological and Demographic Perspectives, University of Hawaii Press, Honolulu.

Kohl, P. L. (2008). Shared social fields: Evolutionary convergence in prehistory and contemporary practice. American Anthropologist 110: 495-506.

Kohler, T. A. (1992). Prehistoric human impact on the environment in the upland North American Southwest. Population and Environment 13: 255-268.

Kohler, T. A., and Matthews, M. H. (1988). Long-term Anasazi land use and forest reduction: A case study from southwest Colorado. American Antiquity 53: 537-564.

Kolata, A. L. (1993). The Tiwanaku: Portrait of an Andean Civilization, Wiley-Blackwell, London.

Kolata, A. L., and Ortloff, C. (1996). Agroecological perspectives on the decline of the Tiwanaku state. In Kolata, A. L. (ed.), Tiwanaku and Its Hinterland, Smithsonian Institution Press, Washington, DC, pp. 181-202.

Kolata, A. L., Binford, M. W., Brenner, M., Janusek, J. W., and Ortloff, C. (2000). Environmental thresholds and the empirical reality of state collapse: A response to Erickson (1999). Antiquity 74: 424-426.

Kramer-Hajos, M., and O'Neill, K. (2008). The Bronze Age site of Mitrou in East Lokris: Finds from the 1988-1989 surface survey. Hesperia 77: 163-250.

Kuniholm, P. I. (1990). Archaeological evidence and non-evidence for climatic change. Philosophical Transactions of the Royal Society of London, Series A, Mathematical and Physical Sciences 330: 645-655.

Kuzucuoglu, C., and Marro, C. (eds.) (2007). Human Societies and Climate Change at the End of the Third Millenium: Did a Crisis Take Place in Upper Mesopotamia? (Societes humaines et 
changement climatique a la fin du troisieme millenaire: Une crise a-t-elle eu lieu en haute Mesopotamie?), Institut Francais d'Etudes Anatoliennes Georges-Dumezil, Istanbul.

Lahiri, N. (ed.) (2000). The Decline and Fall of the Indus Civilization, Permanent Black, Delhi.

Lawler, A. (2008). Indus collapse: The end or beginning of an Asian culture? Science 320: 1281-1283.

Lawler, A. (2010). Collapse? What collapse? Societal change revisited. Science 330: 907-909.

Lemos, I. S. (2002). The Protogeometric Aegean, Oxford University Press, Oxford.

Lemos, I. S. (2010). Lefkandi: Out of the dark. Current World Archaeology 39: 18-27.

Leroy, S. A. (2006). From natural hazard to environmental catastrophe: Past and present. Quaternary International 158: 4-12.

Leroy, S. A., Marco, S., Bookman, R., and Miller, C. S. (2010). Impact of earthquakes on agriculture during the Roman-Byzantine period from pollen records of the Dead Sea laminated sediment. Quaternary Research 73: 191-200.

Lewis, B. (1975). History: Remembered, Recovered, Invented, Princeton University Press, Princeton, NJ.

Lewis, K. (2010). Did they fail? Could they choose? Science 327: 413-414.

Lewis, M. E. (2007). The Early Chinese Empires: Qin and Han, Harvard University Press, Cambridge, MA.

Lewit, T. (2003). 'Vanishing villas': What happened to elite rural habitation in the West in the $5^{\text {th }}-6^{\text {th }} c$. ? Journal of Roman Archaeology 16: 260-274.

Lewit, T. (2009). Pigs, presses and pastoralism: Farming in the fifth to sixth centuries AD. Early Medieval Europe 17: 77-91.

Leyden, B. W., Brenner, M., and Dahlin, B. H. (1998). Cultural and climatic history of Cobá, a lowland Maya city in Quintana Roo, Mexico. Quaternary Research 49: 111-122.

Li, F. (2006). Landscape and Power in Early China: The Crisis and Fall of the Western Zhou, Cambridge University Press, Cambridge.

Liebeschuetz, J. H. (2003). The Decline and Fall of the Roman City, Oxford University Press, Oxford.

Lincoln, C. E. (1989). Review of Yoffee, N., and Cowgill, G. L. (eds.), The Collapse of Ancient States and Civilizations [1988]. Journal of Field Archaeology 16: 461-467.

Linden, E. (2007). The Winds of Change: Climate, Weather, and the Destruction of Civilizations, Simon and Schuster, New York.

Little, L. K. (ed.) (2007). Plague and the End of Antiquity: The Pandemic of 541-750, Cambridge University Press, Cambridge.

Liverani, M. (2001). The fall of the Assyrian empire: Ancient and modern interpretations. In Alcock, S. E., D’Altroy, T. N., Morrison, K. D., and Sinopoli, C. M. (eds.), Empires, Cambridge University Press, Cambridge, pp. 374-391.

Loseby, S. T. (2000). Power and towns in late Roman Britain and early Anglo-Saxon England. In Ripoll, G., and Gurt, J. M. (eds.), Sedes Regiae (ann. 400-800), Reial Acadèmia de Bones Lletres, Barcelona, pp. 319-370.

Lovell, W. G. (1994). Conquest and population: Maya demography in historical perspective. Latin American Research Review 29: 133-140.

Lowe, P., Whitman, G., and Phillipson, J. (2009). Ecology and the social sciences. Journal of Applied Ecology 46: 297-305.

Luce, J. V., and Bolton, K. (1976). Thera and the devastation of Minoan Crete: A new interpretation of the evidence. American Journal of Archaeology 80: 9-18.

Lucero, L. J. (2002). The collapse of the Classic Maya: A case for the role of water. American Anthropologist 104: 814-826.

Lynnerup, N. (1996). Palaeodemography of the Greenland Norse. Arctic Anthropology 33: 122-136.

MacDonald, C. (2010). Knossos. In Cline, E. H. (ed.), The Oxford Handbook of the Bronze Age Aegean, Oxford University Press, Oxford, pp. 529-542.

Mackil, E. (2004). Wandering cities: Alternatives to catastrophe in the Greek polis. American Journal of Archaeology 108: 493-516.

MacMillan, M. (2010). The Uses and Abuses of History, Profile Books, London.

Madella, M., and Fuller, D. Q. (2006). Palaeoecology and the Harappan civilisation of South Asia: A reconsideration. Quaternary Science Reviews 25: 1283-1301.

Maher, L. A., Banning, E. B., and Chazan, M. (2011). Oasis or mirage? Assessing the role of abrupt climate change in the prehistory of the southern Levant. Cambridge Archaeological Journal 21: 1-29.

Mann, D., Edwards, J., Chase, J., Beck, W., Reanier, R., Mass, M., Finney, B., and Loret, J. (2008). Drought, vegetation change, and human history on Rapa Nui (Isla de Pascua, Easter Island). Quaternary Research 69: 16-28. 
Manning, S. W. (2006-2007). Why radiocarbon dating 1200 BCE is difficult: A sidelight on dating the end of the Late Bronze Age and the contrarian contribution. Scripta Mediterranea 27/28: 53-80.

Manning, S. W. (2007). Clarifying the 'high' v. 'low' Aegean/Cypriot chronology for the mid second millennium BC: Assessing the evidence, interpretive frameworks, and current state of the debate. In Bietak, M., and Czerny, E. (eds.), The Synchronisation of Civilisations in the Eastern Mediterranean in the Second Millennium BC III, Verlag der Österreichischen Akademie der Wissenschaften, Austrian Academy of Sciences Press, Vienna, pp. 101-138.

Manning, S. W. (2008). Protopalatial Crete: Formation of the palaces. In Shelmerdine, C. W. (ed.), The Cambridge Companion to the Aegean Bronze Age, Cambridge University Press, Cambridge, pp. $105-120$.

Manning, S. W. (2010). Eruption of Thera/Santorini. In Cline, E. H. (ed.), The Oxford Handbook of the Bronze Age Aegean, Oxford, Oxford University Press, pp. 457-474.

Manning, S. W., Ramsey, C. B., Kutschera, W., Higham, T., Kromer, B., Steier, P., and Wild, E. (2006). Chronology for the Aegean Late Bronze Age 1700-1400 BC. Science 312: 565-569.

Manzanilla, L. (1997). The impact of climatic change on past civilizations: A revisionist agenda for further investigation. Quaternary International 43/44: 153-159.

Maran, J. (2001). Political and religious aspects of architectural change on the Upper Citadel of Tiryns: The case of Building T. In Laffineur, R., and Hagg, R. (eds.), Potnia: Deities and Religion in the Aegean Bronze Age, Aegaeum 22, University of Liège, Liège, pp. 113-122.

Maran, J. (2002). Tiryns town after the fall of the palace: Some new insights. Bulletin of the Institute of Classical Studies 46: 223-224.

Maran, J. (2006). Coming to terms with the past: Ideology and power in Late Helladic IIIC. In DegerJalkotzy, S., and Lemos, I. S. (eds.), Ancient Greece from the Mycenaean Palaces to the Age of Homer, Edinburgh University Press, Edinburgh, pp. 123-150.

Marcus, J. (1998). The peaks and valleys of ancient states: An extension of the dynamic model. In Feinman, G. M., and Marcus, J. (eds.), Archaic States, School of American Research Press, Santa Fe, NM, pp. 59-94.

Marinatos, S. (1939). The volcanic destruction of Minoan Crete. Antiquity 13: 425-439.

Masse, W. B., Barber, E. W., Piccardi, L., and Barber, P. T. (2007). Exploring the nature of myth and its role in science. In Piccardi, L., and Masse, W. B. (eds), Myth and Geology, Special Publications 273, Geological Society, London, pp. 9-28.

Masson, M. A. (1997). Cultural transformation at the Maya Postclassic community of Laguna de On, Belize. Latin American Antiquity 8: 293-316.

Masson, M. A., and Mock, S. B. (2004). Ceramics and settlement patterns at Terminal Classic-period lagoon sites in northeastern Belize. In Demarest, A. A., Rice, P. M., and Rice, D. S. (eds.), The Terminal Classic in the Maya Lowlands: Collapse, Transition, and Transformation, University Press of Colorado, Boulder, pp. 367-401.

Masson, M. A., Hare, T. S., and Peraza Lope, C. (2006). Postclassic Maya society regenerated at Mayapan. In Schwartz, G. M., and Nichols, J. J. (eds.), After Collapse: The Regeneration of Complex Societies, University of Arizona Press, Tucson, pp. 188-207.

Matthews, R. (2004). Landscapes of terror and control: Imperial impacts in Paphlagonia. Near Eastern Archaeology 67: 200-211.

Mayewski, P. A., Rohling, E. E., Stager, J. C., Karlen, W., Maasch, K. A., Meeker, L. D., Meyerson, E. A., Gasse, F., van Krevald, S., Holmgren, K., Lee-Thorp, J., Rosqvist, G., Rack, F., Staubwasser, M., Schneider, R. R., and Steig, E. J. (2004). Holocene climate variability. Quaternary Research 62 : 243-255.

McAnany, P. A., and Negron, T. G. (2010). Bellicose rulers and climatological peril? Retrofitting twentyfirst century woes on eighth century Maya society. In McAnany, P. A., and Yoffee, N. (eds.), Questioning Collapse: Human Resilience, Ecological Vulnerability, and the Aftermath of Empire, Cambridge University Press, Cambridge, pp. 142-175.

McAnany, P. A., and Yoffee, N. (eds.) (2010a). Questioning Collapse: Human Resilience, Ecological Vulnerability, and the Aftermath of Empire, Cambridge University Press, Cambridge.

McAnany, P. A., and Yoffee, N. (2010b). Why we question collapse. In McAnany, P. A., and Yoffee, N. (eds.), Questioning Collapse: Human Resilience, Ecological Vulnerability, and the Aftermath of Empire, Cambridge University Press, Cambridge, pp. 1-17.

McAnany, P. A., and Yoffee, N. (2010c). Questioning how different societies respond to crises. Nature 464: 977. 
McCoy, F. W., and Heiken, G. (2000). Tsunami generated by the Late Bronze Age eruption of Thera (Santorini), Greece. Pure and Applied Geophysics 157: 1227-1256.

McEwan, G. F. (2006). Inca state origins: Collapse and regeneration in the southern Peruvian Andes. In Schwartz, G. M., and Nichols, J. J. (eds.), After Collapse: The Regeneration of Complex Societies, University of Arizona Press, Tucson, pp. 85-98.

McGovern, T. H. (1991). Climate, correlation, and causation in Norse Greenland. Arctic Anthropology 28: $77-100$.

McGovern, T. H., Bigelow, G., Amorosi, T., and Russell, D. (1988). Northern islands, human error, and environmental degradation: A view of social and ecological change in the medieval North Atlantic. Human Ecology 16: 225-270.

McGuire, R. H. (1992). Archeology and the first Americans. American Anthropologist 94: 816-836.

McGuire, R. H., and Walker, M. (1999). Class confrontations in archaeology. Historical Archaeology 33(1): 159-183.

McMenamin, D. (2006). Anglo-Indian experiences during partition and its impact upon their lives. New Zealand Journal of Asian Studies 8: 69-95.

McNeil, C. L., Burney, D. A., and Burney, L. P. (2010). Evidence disputing deforestation as the cause for the collapse of the ancient Maya polity of Copan, Honduras. Proceedings of the National Academy of Sciences 107: 1017-1022.

McNeill, J. R. (2010). Sustainable survival. In McAnany, P. A., and Yoffee, N. (eds.), Questioning Collapse: Human Resilience, Ecological Vulnerability, and the Aftermath of Empire, Cambridge University Press, Cambridge, pp. 355-366.

Michalowski, P. (2008). The mortal kings of Ur: A short century of divine rule in ancient Mesopotamia. In Brisch, N. (ed.), Religion and Power: Divine Kingship in the Ancient World and Beyond, Oriental Institute of Chicago, Chicago, pp. 33-45.

Middleton, G. D. (2010). The Collapse of Palatial Society in Late Bronze Age Greece and the Postpalatial Period, BAR International Series 2110, Archaeopress, Oxford.

Mieth, A., and Bork, H.-R. (2010). Humans, climate or introduced rats: Which is to blame for the woodland destruction on prehistoric Rapa Nui (Easter Island)? Journal of Archaeological Science 37: $417-426$.

Milbraith, S., and Peraza Lope, C. (2003). Revisiting Mayapan: Mexico's last Maya capital. Ancient Mesoamerica 14: 1-46.

Mills, B. J. (2002). Recent research on Chaco: Changing views on economy, ritual, ands society. Journal of Archaeological Research 10: 65-117.

Mills, B. J. (2004). Key debates in Chacoan archaeology. In Noble, D. G. (ed.), In Search of Chaco: New Approaches to an Archaeological Enigma, School of American Research Press, Santa Fe, NM, pp. 123-130.

Milner, G. R. (1990). The Late Prehistoric Cahokia cultural system of the Mississippi River Valley: Foundations, florescence, and fragmentation. Journal of World Prehistory 4: 1-43.

Minoura, K., Imamura, F., Kuran, U., Nakamura, T., Papadopoulos, G. A., Takahashi, T., and Yalciner, A. C. (2000). The discovery of Minoan tsunami deposits. Geology 28: 59-62.

Mitchell, P. (2008). Practising archaeology at a time of climatic catastrophe. Antiquity 82: 1093-1103.

Modelski, G. (2007). Ages of reorganization. In Hornborg, A., and Crumley, C. L. (eds.), The World System and the Earth System: Global Socioenvironmental Change and Sustainability since the Neolithic, Left Coast Press, Walnut Creek, CA, pp. 180-194.

Mommsen, T. E. (1942). Petrarch's conception of the “dark ages.” Speculum 17: 226-242.

Monaco, C., and Tortorici, L. (2004). Faulting and effects of earthquakes on Minoan archaeological sites in Crete (Greece). Tectonophysics 382: 103-116.

Montazeri, A., Baradaran, H., Omidvari, S., Ali Azin, S., Ebadi, M., Garmaroudi, G., Haririchi, A. M., and Shariati, M. (2005). Psychological distress among Bam earthquake survivors in Iran: A population based study. BMC Public Health 5: article 4, doi:10.1186/1471-2458-5-4.

Morris, E. (2006). "Lo, nobles lament, the poor rejoice": State formation in the wake of social flux. In Schwartz, G. M., and Nichols, J. J. (eds.), After Collapse: The Regeneration of Complex Societies, University of Arizona Press, Tucson, pp. 58-71.

Morris, I. (1997). Periodisation and the heroes: inventing a dark age. In Golden, M., and Toohey, P. (eds.), Inventing Ancient Culture: Historicism, Periodization, and the Ancient World, Routledge, London, pp. 96-131.

Morris, I. (2006). The collapse and regeneration of complex society in Greece, 1500-500 BC. In Schwartz, G. M., and Nichols, J. J. (eds.), After Collapse: The Regeneration of Complex Societies, University of Arizona Press, Tucson, pp. 72-84. 
Motyl, A. J. (2001). Imperial Ends: The Decay, Collapse and Revival of Empires, Columbia University Press, New York.

Moyer, M. (2010). Eternal fascinations with the end. Scientific American 303: 38-40.

Nelson, M. C., Hegmon, M., Kulow, S., and Schollmeyer, K. G. (2006). Archaeological and ecological perspectives on reorganization: A case study from the Mimbres region of the US Southwest. American Antiquity 71: 403-432.

Neumann, J. (1993). Climatic changes in Europe and the Near East in the second millennium. Climatic Change 23: 231-245.

Neumann, J., and Parpola, S. (1987). Climatic change and the eleventh-tenth-century eclipse of Assyria and Babylonia. The Journal of Near Eastern Studies 46: 161-182.

Nissenbaum, A. (1994). Sodom, Gomorrah and the other lost cities of the Plain: A climatic perspective. Climatic Change 26: 435-446.

Nowicki, K. (2000). Defensible Sites in Crete c.1200-800 BC, Aegaeum 21, University of Liège, Liège.

Nunn, P. D. (2000). Environmental catastrophe in the Pacific Islands around AD 1300. Geoarchaeology 15: $715-740$.

Nunn, P. D., Hunter-Anderson, R., Carson, M. T., Thomas, F., Ulm, S., and Rowland, M. J. (2007). Times of plenty, times of less: Last-millennium societal disruption in the Pacific Basin. Human Ecology 35 : $385-401$.

Nur, A. (1998). The end of the Bronze Age by large earthquakes? In Peiser, B. J., Palmer, T., and Bailey, M. E. (eds.), Natural Catastrophes During Bronze Age Civilisations: Archaeological, Geological, Astronomical and Cultural Perspectives, BAR International Series 728, Archaeopress, Oxford, pp. 140-147.

Nur, A., and Burgess, D. (2008). Apocalypse: Earthquakes, Archaeology and the Wrath of God, Princeton University Press, Princeton, NJ.

Nur, A., and Cline, E. H. (2000). Poseidon's horses: Plate tectonics and earthquake storms in the Late Bronze Age Aegean and eastern Mediterranean. Journal of Archaeological Science 27: 43-63.

Oglesby, R. J., Sever, T. L., Saturno, W., Erickson, D. J., and Srikishen, J. (2010). Collapse of the Maya: Could deforestation have contributed? Journal of Geophysical Research 115: D12106, 1-10.

Orlove, B. (2005). Human adaptation to climate change: A review of three historical cases and some general perspectives. Environmental Science and Policy 8: 589-600.

Owen, B. D. (2005). Distant colonies and explosive collapse: The two stages of the Tiwanaku diaspora in the Osmore drainage. Latin American Antiquity 16: 45-80.

Palka, J. W. (2009). Historical archaeology of indigenous culture change in Mesoamerica. Journal of Archaeological Research 17: 297-346.

Panagiotakopulu, E., Skidmore, P., and Buckland, P. (2007). Fossil insect evidence for the end of the Western Settlement in Norse Greenland. Naturewissenschaften 94: 300-306.

Parkinson, W. A., and Galaty, M. L. (eds.) (2009). Archaic State Interaction: The Eastern Mediterranean in the Bronze Age, School for Advanced Research Press, Santa Fe, NM.

Pauketat, T. R. (2004). Ancient Cahokia and the Mississippians, Cambridge University Press, Cambridge.

Paulson, A. (1976). Environment and empire: Climatic factors in prehistoric Andean culture change. World Archaeology 8: 121-132.

Peiser, B. (2005). From genocide to ecocide: The rape of Rapa Nui. Energy and Environment 16: 513-539.

Pendergast, D. M. (1993). The center and the edge: Archaeology in Belize, 1809-1992. Journal of World Prehistory 7: 1-33.

Piccardi, L., and Masse, B. (eds.) (2007). Myth and Geology, Special Publications 273, Geological Society, London.

Pichler, H., and Schiering, W. (1977). The Thera eruption and Late Minoan-IB destructions on Crete. Nature 267: 819-822.

Plog, S. (2008). Ancient Peoples of the American Southwest, 2nd ed., Thames and Hudson, London.

Pluciennik, M. (1999). Archaeological narratives and other ways of telling. Current Anthropology 40: 653-678.

Plunket, P., and Uruñuela, G. (2000). The archaeology of a plinian eruption of the Popocatepetl volcano. In McGuire, W. G., Griffiths, D. R., Hancock, P. L., and Stewart, I. S. (eds.), The Archaeology of Geological Catastrophes, Special Publications 171, Geological Society, London, pp. 195-203.

Pohl, W. (ed.) (1997). Kingdoms of the Empire: The Integration of Barbarians in Late Antiquity, The Transformation of the Roman World, vol. 1, Leiden, Brill. 
Pollock, S. (1999). Ancient Mesopotamia: The Eden that Never Was, Cambridge University Press, Cambridge.

Ponting, C. (2007). A New Green History of the World: The Environment and the Collapse of the Great Civilizations, rev. ed., Penguin, London.

Popham, M. (1994). The collapse of Aegean civilization at the end of the Late Bronze Age. In Cunliffe, B. (ed.), The Oxford Illustrated Prehistory of Europe, Oxford University Press, Oxford, pp. 277-303.

Posnansky, A. (1945). Tihuanacu: The Cradle of American Man, J. J. Augustin, New York.

Possehl, G. L. (1997). The transformation of the Indus civilization. Journal of World Prehistory 11: $425-472$.

Possehl, G. L. (1998). Sociopolitical complexity without the state: The Indus civilization. In Feinman, G. M., and Marcus, J. (eds.), Archaic States, School of American Research Press, Santa Fe, NM, pp. 261-291.

Powell, M. (1985). Salt, seed, and yields in Sumerian agriculture: A critique of the theory of progressive salinization. Zeitschrift für Assyriologie 75: 7-38.

Preston, L. (2008). Late Minoan II to IIIB Crete. In Shelmerdine, C. W. (ed.), The Cambridge Companion to the Aegean Bronze Age, Cambridge University Press, Cambridge, pp. 310-326.

Preucel, R. W., and Mrozowski, S. A. (eds.) (2010). Contemporary Archaeology in Theory: The New Pragmatism, 2nd ed., Wiley-Blackwell, Chichester, UK.

Pringle, H. (2009). A new look at the Mayas' end. Science 324: 454-456.

Pyle, D. M. (1997). The global impact of the Minoan eruption of Santorini, Greece. Environmental Geology 30: 59-61.

Rainbird, P. (2002). A message for our future? The Rapa Nui (Easter Island) ecodisaster and Pacific island environments. World Archaeology 33: 436-451.

Ramsey, C. B., Dee, M. W., Rowland, J. M., Higham, T. F., Harris, S. A., Brock, F., Quiles, A., Wild, E. M., Marcus, E. S., and Shortland, A. J. (2010). Radiocarbon-based chronology for dynastic Egypt. Science 328: 1554-1557.

Rappaport, R. A. (1977). Maladaptation in social systems. In Friedman, J., and Rolands, M. (eds.), Evolution in Social Systems, Duckworth, London, pp. 49-71.

Redman, C. L. (1999). Human Impact on Ancient Environments, University of Arizona Press, Tucson.

Redman, C. L. (2004). Environmental degradation and early Mesopotamian civilization. In Redman, C. L., James, S. R., Fish, P. R., and Rogers, J. D. (eds.), The Archaeology of Global Change: The Impact of Humans on Their Environment, Smithsonian Books, Washington, DC, pp. 158-164.

Redman, C. L. (2005). Resilience theory in archaeology. American Anthropologist 107: 70-77.

Redman, C. L., James, S. R., Fish, P. R., and Rogers, J. D. (eds.) (2004). The Archaeology of Global Change: The Impact of Humans on Their Environment, Smithsonian Books, Washington, DC.

Rempel, J., and Yoffee, N. (1999). The end of the cycle? Assessing the impact of Hellenization on Mesopotamian civilization. In Bock, B., Cancik-Kirschbaum, E., and Richter, T. (eds.), Munuscula Mesopotamica: Festschrift fur Johannes Renger, Ugarit-Verlag, Munster, pp. 385-398.

Ren, A. C. (2006). Maya archaeology and the political and cultural identity of contemporary Maya in Guatemala. Archaeologies 2: 8-19.

Reycraft, M. R., and Bawden, G. (2000). Introduction. In Bawden, G., and Reycraft, R. M. (eds.), Environmental Disaster and the Archaeology of Human Response, Anthropological Papers No. 7 , Maxwell Museum of Anthropology, Albuquerque, NM, pp. 1-10.

Richer, P. J., Boyd, R., and Bettinger, R. L. (2001). Was agriculture impossible during the Pleistocene but mandatory during the Holocene? A climate change hypothesis. American Antiquity 66: 387-411.

Roberts, N., Eastwood, W. J., Kuzucuoglu, C., Fiorentino, G., and Caracuta, V. (2011). Climatic, vegetation, and cultural change in the eastern Mediterranean during the mid-Holocene environmental transition. The Holocene 21: 147-162.

Robertson, P. (2010). A catastrophic collapse. Currents 20: 22-28.

Rose, M. (1999). Godzilla's attacking Babylon! Archaeology. Available at: http://www.archaeology. org/online/features/godzilla/ (accessed 18/6/10).

Rubertone, P. E. (2000). The historical archaeology of Native Americans. Annual Review of Anthropology 29: 425-446.

Rull, V., Cañellas-Boltà, N., Sáez, A., Giralt, S., Pla, S., and Margalef, O. (2010). Palaeoecology of Easter Island: Evidence and uncertainties. Earth Science Reviews 99: 50-60.

Runnels, C. N. (1995). Environmental degradation in ancient Greece. Scientific American 272: 96-99.

Runnels, C. N. (2000). Anthropogenic soil erosion in prehistoric Greece: The contribution of regional surveys to the archaeology of environmental disruptions and human response. In Bawden, G., and 
Reycraft, R. M. (eds.), Environmental Disaster and the Archaeology of Human Response, Anthropological Papers No. 7, Maxwell Museum of Anthropology, Albuquerque, NM, pp. 11-20. Rutter, J. B. (1992). Cultural novelties in the post-palatial Aegean world: Indices of vitality or decline? In Ward, W. A., and Joukowsky, M. S. (eds.), The Crisis Years: The 12th Century BC: From Beyond the Danube to the Tigris, Kendall/Hunt Publishing, Dubuque, IA, pp. 61-78.

Rystedt, E. (1999). No words, only pictures: Iconography in the transition between the Bronze and Iron Age in Greece. Opuscula Atheniensia 24: 89-98.

Sanderson, S. K. (2005). Revolutions: A Worldwide Introduction to Political and Social Change, Paradigm, Boulder, CO.

Santley, R. S., Nelson, S. A., Reinhardt, B. K., Pool, C. A., and Arnold, P. J. (2000). When day turned to night: Volcanism and the archaeological record from the Tuxtla Mountains, southern Veracruz, Mexico. In Bawden, G., and Reycraft, R. M. (eds.), Environmental Disaster and the Archaeology of Human Response, Anthropological Papers No. 7, Maxwell Museum of Anthropology, Albuquerque, NM, pp. 143-162.

Sarris, P. (2009). Introduction: Aristocrats, peasants, and the transformation of rural society, c. 400-800. Journal of Agrarian Change 9: 3-22.

Saunders, N. (2000). Blown away. New Scientist 165: 48.

Scarborough, V. (2007). The rise and fall of the ancient Maya: A case study in political ecology. In Costanza, R., Graumlich, L. J., and Steffen, W. (eds.), Sustainability or Collapse? An Integrated History and Future of People on Earth, MIT Press, Cambridge, pp. 51-60.

Scarborough, V. (2009). The archaeology of sustainability: Mesoamerica. Ancient Mesoamerica 20: 197-203.

Schaeffer, C. F. (1948). Stratigraphie compare é et chronologie de l'Asie Occidentale, Oxford University Press, Oxford.

Scheffer, M., Carpenter, S., Foley, J. A., Folkes, C., and Walker, B. (2001). Catastrophic shifts in ecosystems. Nature 413: 591-596.

Schiettecatte, J. (2010). Why did the cities of the Jawf Valley collapse ? An archaeo-geographical approach. In Alarashi, H., Chambrade, M.-L., Gondet, S., Jouvenel, A., Sauvage, C., and Tronchère, H. (eds.), Regards croisés sur l'étude archéologique des paysages anciens: nouvelles recherches dans le Bassin méditerranéen, en Asie centrale et au Proche et au Moyen-Orient, Travaux de la Maison de l'Orient et de la Méditerranée 56, Maison de l'Orient et de la Méditerranée Jean Pouilloux, Lyon, pp. 149-161.

Schoep, I. (2010). Crete. In Cline, E. H. (ed.), The Oxford Handbook of the Bronze Age Aegean, Oxford, Oxford University Press, pp. 113-125.

Schwartz, G. M. (2006). From collapse to regeneration. In Schwartz, G. M., and Nichols, J. J. (eds.), After Collapse: The Regeneration of Complex Societies, University of Arizona Press, Tucson, pp. 3-17.

Schwartz, G. M., and Nichols, J. J. (eds.) (2006). After Collapse: The Regeneration of Complex Societies, University of Arizona Press, Tucson.

Shaughnessy, E. L. (1999). Western Zhou history. In Loewe, M., and Shaughnessy, E. L. (eds.), The Cambridge Ancient History of China, Cambridge University Press, Cambridge, pp. 292-351.

Shaw, B., Ambraseys, N. N., England, P. C., Floyd, M. A., Gorman, G. J., Higham, T. F., Jackson, J. A., Nocquet, J.-M., Pain, C. C., and Piggott, M. D. (2008). Eastern Mediterranean tectonics and tsunami hazard inferred from the AD 365 earthquake. Nature Geoscience 1: 268-276.

Shelmerdine, C. W. (2001). The Palatial Bronze Age of the southern and central Greek mainland. In Cullen, T. (ed.), Aegean Prehistory: A Review, Archaeological Institute of America, Boston, pp. 329-381.

Sherratt, E. S. (1990) "Reading the texts": Archaeology and the Homeric question. Antiquity 64: $807-824$.

Sherratt, E. S. (2001). Potemkin palaces and route-based economies. In Voutsaki, S., and Killen, J. (eds.), Economy and Politics in the Mycenaean Palace States, Cambridge Philological Society, Cambridge, pp. 214-238.

Sherratt, E. S. (2003). The Mediterranean economy: 'Globalization' at the end of the second millennium BCE. In Dever, W. G., and Gitin, S. (eds.), Symbiosis, Symbolism, and the Power of the Past: Canaan, Ancient Israel, and Their Neighbors from the Late Bronze Age through Roman Palaestina, Eisenbrauns, Winona Lake, WI, pp. 37-62.

Sherratt, E. S. (2006). LH IIIC Lefkandi: An overview. In Evely, D. (ed.), Lefkandi IV The Bronze Age: The Late Helladic IIIC Settlement at Xeropolis, The British School at Athens, London, pp. 303-309. 
Shimada, I., Schaaf, C. B., Thompson, L. G., and Mosley-Thompson, E. (1991). Cultural impacts of severe droughts in the prehistoric Andes: Application of a 1,500 years ice core precipitation record. World Archaeology 22: 247-270.

Silberman, N. A. (1998). The Sea Peoples, the Victorians, and us: Modern social ideology and changing interpretations of the Late Bronze Age collapse. In Gitin, S., Mazar, A., and Stern, E. (eds.), Mediterranean Peoples in Transition: Thirteenth to Early Tenth Centuries BCE, Israel Exploration Society, Jerusalem, pp. 268-275.

Silliman, S. W. (2005). Culture contact or colonialism? Challenges in the archaeology of native North America. American Antiquity 70: 55-74.

Sims, K. (2006). After state collapse: How Tumilaca communities developed in the upper Moquega Valley, Peru. In Schwartz, G. M., and Nichols, J. J. (eds.), After Collapse: The Regeneration of Complex Societies, University of Arizona Press, Tucson, pp. 114-136.

Sinopoli, C. M. (1994). The archaeology of empires. Annual Review of Anthropology 23: 159-180.

Siverstein, B. J. (2009). The Parting of the Sea: How Volcanoes, Earthquakes and Plagues Shaped the Story of Exodus, Princeton University Press, Princeton, NJ.

Smith, M. L. (2006). The archaeology of South Asian cities. Journal of Archaeological Research 14: 97-142.

Staubwasser, M., and Weiss, H. (2006). Holocene climate and cultural evolution in late prehistoric-early historic west Asia. Quaternary Research 66: 372-387.

Stewart, I. (2008). Review of Nur, A., and Burgess, D., Apocalypse: Earthquakes, Archaeology and the Wrath of God [2008]. Times Higher Education Supplement. Available at: http://www.timeshigher education.co.uk/story.asp?storyCode $=402835 \&$ sectioncode $=26$ (accessed 11/6/10).

Stiebing, W. H. (1980). The end of the Mycenean Age. The Biblical Archaeologist 43: 7-21.

Stiros, S. C. (2001). The AD 365 earthquake and possible seismic clustering during the fourth to sixth centuries AD in the eastern Mediterranean: A review of historical and archaeological data. Journal of Structural Geology 23: 545-562.

Stiros, S. C. (2009). Review of Nur, A., and Burgess, D., Apocalypse: Earthquakes, Archaeology and the Wrath of God [2008]. The Classical Review 59: 572-574.

Stiros, S. C., and Jones, R. E. (eds.) (1996). Archaeoseismology, The British School at Athens and Institute of Geology and Mineral Exploration, Athens.

Stone, E. C. (2002). The Ur III-Old Babylonian transition: An archaeological perspective. Iraq 64: 79-84.

Suhler, C., Ardren, T., Freidel, D., and Johnstone, D. (2004). The rise and fall of terminal classic Yaxuna, Yucatan, Mexico. In Demarest, A. A., Rice, P. M., and Rice, D. S. (eds.), Terminal Classic in the Maya Lowlands: Collapse, Transition and Transformation, University Press of Colorado, Boulder, pp. 450-484.

Svensen, H. (2009). The End is Nigh: A History of Natural Disasters, Reaktion Books, London.

Tainter, J. A. (1988). The Collapse of Complex Societies, Cambridge University Press, Cambridge.

Tainter, J. A. (1999). Post-collapse societies. In Barker, G. (ed.), Companion Encyclopedia of Archaeology, Routledge, London, pp. 988-1039.

Tainter, J. A. (2006a). Archaeology of overshoot and collapse. Annual Review of Anthropology. 35: 59-74.

Tainter, J. A. (2006b). Social complexity and sustainability. Ecological Complexity. 3: 91-103.

Tainter, J. A. (2008). Collapse, sustainability, and the environment: How authors choose to fail or succeed. Reviews in Anthropology 37: 342-371.

Tainter, J. A. (2010). Review of McAnany, P. A., and Yoffee, N. (eds.), Questioning Collapse: Human Resilience, Ecological Vulnerability, and the Aftermath of Empire [2010]. Human Ecology 38: 709-710.

Tartaron, T. F. (2010). Between and beyond: Political economy in non-palatial Mycenaean worlds. In Pullen, D. (ed.), Political Economies of the Aegean Bronze Age, Papers from the Langford Conference, Florida State University, Tallahassee, 22-24 February 2007, Oxbow Books, Oxford, pp. 161-183.

The Millennium Project (1997). The third round questionnaire for the historical panel. Available at: http://www.millennium-project.org/millennium/loh-rd3.html (accessed 22/8/10).

Thomatos, M. (2006). The Final Revival of the Aegean Bronze Age: A Case Study of the Argolid, Corinthia, Attica, Euboea, the Cyclades and the Dodecanese during LH IIIC Middle, Archaeopress, Oxford.

Thompson, L. G., Mosley-Thompson, E., Bolzan, J. F., and Koci, B. R. (1985). A 1500-year record of tropical precipitation in ice cores from the Quelccaya ice cap, Peru. Science 229: 971-973. 
Thompson, T. J. (2005). Ancient stateless civilization: Bronze Age India and the state in history. The Independent Review 10: 365-384.

Thompson, W. R. (2004). Complexity, diminishing marginal returns, and serial Mesopotamian fragmentation. Journal of World Systems Research 10: 613-652.

Thornton, R. (1997). Aboriginal North American population and rates of decline, ca. AD 1500-1900. Current Anthropology 38: 310-315.

Tomkins, P., and Shoep, I. (2010). Crete. In Cline, E. H. (ed.), The Oxford Handbook of the Bronze Age Aegean, Oxford University Press, Oxford, pp. 66-82.

Town, M. S., Warren, S. G., Walde, V. P., and Waddington, E. D. (2008). Effect of atmospheric water vapor on modification of stable isotopes in near-surface snow on ice sheets. Journal of Geophysical Research D 113: D24303, doi:10.1029/2008JD009852.

Trigger, B. G. (1989). A History of Archaeological Thought, Cambridge University Press, Cambridge.

Tsonis, A. A., Swanson, K. L., Sugihara, G., and Tsonia, P. A. (2010). Climate change and the demise of the Minoan civilization. Climate of the Past 6: 525-530.

Turchin, P. (2006). War and Peace and War: The Rise and Fall of Empires, Plume, New York.

Ur, J. A. (2010). Cycles of civilization in northern Mesopotamia. Journal of Archaeological Research 18: 387-431.

Van De Mieroop, M. (2007). A History of the Ancient Near East: Ca. 3000-323 BC, 2nd ed., Blackwell, London.

Van De Mieroop, M. (2010). The Eastern Mediterranean in the Age of Ramesses II, Wiley-Blackwell, Chichester, UK.

Van De Moortel, A., and Zahou, E. (2005). 2004 excavations at Mitrou, East Lokris. Aegean Archaeology 7: $39-48$.

Van Dommelen, P. (1997). Colonial constructs: Colonialism and archaeology in the Mediterranean. World Archaeology 28: 305-323.

Van Engelsdorp, D., Evans, J. D., Saergerman, C., Mullin, C., Haubruge, E., Nguyen, B. K., Frazier, J., Cox-Foster, D., Chen, Y., Underwood, R., Tarpy, D. R., and Pettis, J. S. (2009). Colony collapse disorder: A descriptive study. Public Library of Science One 4: e6481.

Vince, G. (2009). Surviving in a warmer world. New Scientist 201: 29-33.

Vuille, M., Bradley, R. S., Werner, M., and Keimig, F. (2003). 20th century climate change in the tropical Andes: Observations and model results. Climate Change 59: 75-99.

Wallace, S. (2006). The gilded cage? Settlement and socioeconomic change after 1200 BC : A comparison of Crete and other Aegean regions. In Deger-Jalkotzy, S., and Lemos, I. S. (eds.), Ancient Greece from the Mycenaean Palaces to the Age of Homer, Edinburgh University Press, Edinburgh, pp. 619-664.

Wallace, S. (2010). Ancient Crete: From Succesful Collapse to Democracy's Alternatives, Twelfth to Fifth Centuries BC, Cambridge University Press, Cambridge.

Walløe, L. (1999). Was the disruption of the Mycenaean world caused by repeated epidemics of bubonic plague? Opuscula Atheniensis 24: 121-126.

Ward-Perkins, B. (2005). The Fall of Rome and the End of Civilization, Oxford University Press, Oxford.

Washington-Allen, R. A., Briske, D. D., Shugart, H. H., and Salo,. L. F. (2009). Introduction to special feature on catastrophic thresholds, perspectives, definitions, and applications. Ecology and Society 15: 38 .

Webster, D. (2002). The Fall of the Ancient Maya: Solving the Mystery of the Maya Collapse, Thames and Hudson, London.

Webster D. (2006). The mystique of the ancient Maya. In Fagan, G. G. (ed.), Archaeological Fantasies: How Pseudoarchaeology Misrepresents the Past and Misleads the Public, Routledge, London, pp. 129-153.

Weiss, H. (1996). Desert storm. The Sciences 36(3): 30-36.

Weiss, H. (1997). Late third millennium abrupt climate change and social collapse in west Asia and Egypt. In Dalfes, H. N., Kukla, G., and Weiss, H. (eds.), Third Millenium BC Climate Change and Old World Collapse, NATO ASI, Series I, Global Environmental Change, Vol. 49, Springer, Berlin, pp. 711-723.

Weiss, H. (2000). Beyond the Younger Dryas: Collapse as adaptation to abrupt climate change in ancient west Asia and the eastern Mediterranean. In Bawden, G., and Reycraft, R. M. (eds.), Environmental Disaster and the Archaeology of Human Response, Anthropological Papers No. 7, Maxwell Museum of Anthropology, Albuquerque, NM, pp. 75-98.

Weiss, H., and Bradley, R. S. (2001). What drives societal collapse? Science 291: 609-610. 
Weiss, H., and Courty, M.-A. (1993). The genesis and collapse of the Akkadian empire: The accidental refraction of historical law. In Liverani, M. (ed.), Akkad: The First World Empire, Sargon, Padova, Italy, pp. 131-156.

Weiss, H., Courty, M.-A., Wetterstrom, W., Guichard, F., Senior, L., Meadow, R., and Curnow, A. (1993). The genesis and collapse of third millennium north Mesopotamian civilization. Science 261: 995-1004.

Wells, B., Runnels, C., and Zangger, E. (1993). In the shadow of Mycenae. Archaeology 46: 54-58.

Whitby, M. (2000). Review of Keys, D., Catastrophe: An Investigation into the Origins of the Modern World [1999]. The Classical Review 50: 350.

Wickham, C. (2009). The Inheritance of Rome: A History of Europe from 400 to 1000, Allen Lane, London.

Wilcox, M. (2010). Marketing conquest and the vanishing Indian: An indigenous response to Jared Diamond's archaeology of the American southwest. In McAnany, P. A., and Yoffee, N. (eds.), Questioning Collapse: Human Resilience, Ecological Vulnerability, and the Aftermath of Empire, Cambridge University Press, Cambridge, pp. 113-141.

Wilk, R. R. (1985). The ancient Maya and the political present. Journal of Anthropological Research 41: 307-326.

Williams, M. (2000). Dark ages and dark areas: Deforestation in the deep past. Journal of Historical Geography 26: 28-46.

Williams, R. P. (2002). Rethinking disaster-induced collapse in the demise of the Andean highland states: Wari and Tiwanaku. World Archaeology 33: 361-374.

Wills, W.H. (2009). Cultural identity and the archaeological construction of historical narratives: An example from Chaco Canyon. Journal of Archaeological Method and Theory 16: 283-319.

Wood, M. (1998). The use of the Pharaonic past in modern Egyptian nationalism. Journal of the American Research Center in Egypt 35: 179-196.

Wossink, A. (2010). Climate, history, and demography: A case study from the Balikh Valley, Syria. In Alarashi, H., Chambrade, M.-L., Gondet, S., Jouvenel, A., Sauvage, C., and Tronchère, H. (eds.), Regards croisés sur l'étude archéologique des paysages anciens: nouvelles recherches dans le Bassin méditerranéen, en Asie centrale et au Proche et au Moyen-Orient, Travaux de la Maison de l'Orient et de la Méditerranée 56, Maison de l'Orient et de la Méditerranée Jean Pouilloux, Lyon, pp. 181-192.

Wright, H. E. (1993). Environmental determinism in Near Eastern prehistory. Current Anthropology 34: 458-469.

Wright, L. E., and White, C. D. (1996). Human biology in the classic Maya collapse: Evidence from paleopathology and paleodiet. Journal of World Prehistory 10: 147-198.

Wright, R. P. (2010). The Ancient Indus: Urbanism, Economy, and Society, Cambridge University Press, Cambridge.

Yasur-Landau, A. (2010). The Philistines and Aegean Migration at the End of the Late Bronze Age, Cambridge University Press, Cambridge.

Yoffee, N. (1988a). Orienting collapse. In Yoffee, N., and Cowgill, G. L. (eds.), Collapse of Ancient States and Civilizations, University of Arizona Press, Tucson, pp. 1-19.

Yoffee, N. (1988b). The collapse of ancient Mesopotamian states and civilization. Yoffee, N., and Cowgill, G. L. (eds.), Collapse of Ancient States and Civilizations, University of Arizona Press, Tucson, pp. 44-68.

Yoffee, N. (2004). Myths of the Archaic State: Evolution of the Earliest Cities, States, and Civilizations, Cambridge University Press, Cambridge.

Yoffee, N. (2010). Collapse in ancient Mesopotamia: What happened, what didn't. In McAnany, P. A., and Yoffee, N. (eds.), Questioning Collapse: Human Resilience, Ecological Vulnerability, and the Aftermath of Empire, Cambridge University Press, Cambridge, pp. 176-203.

Zettler, R. L. (2003). Reconstructing the world of ancient Mesopotamia: Divided beginnings and holistic history. Journal of Economic and Social History of the Orient 46: 3-45.

Zhang, D. D., Jim, C. Y., Lin, G. C., He, Y.-Q., and Lee, F. (2005). Climate change, social unrest and dynastic transition in ancient China. China Science Bulletin 50: 137-144.

Zhang, D. D., Jim, C. Y., Lin, G. C., He, Y.-Q., Wang, J. J., and Lee, H. F. (2006). Climatic change, wars and dynastic cycles in China over the last millennium. Climatic Change 76: 459-477.

Zhang, D. D., Brecke, P., Lee, H. F., He, Y.-Q., and Zhang, J. (2007a). Global climate change, war, and population decline in recent human history. Proceedings of the National Academy of Sciences 104: 19214-19219. 
Zhang, D. D., Zhang, J., Lee, H. F., and He, Y.-Q. (2007b). Climate change and war frequency in eastern China over the last millennium. Human Ecology 35: 403-414.

Zovar, J. M. (2007). Contact, conflict, trade and migration: Interregional interaction in the Andean Late Intermediate Period (1150-1450). Buletinul Cercurilor Stiintifice Studentesti, Arheologie - Istorie Muzeologie 13: 65-78.

\section{Bibliography of recent literature}

Adams, R. E. (1973). The collapse of Maya civilization: A review of previous theories. In Culbert, T. P. (ed.), The Classic Maya Collapse, University of New Mexico Press, Alberquerque, pp. 21-34.

Amesbury, M. J., Charman, D. J., Fyfe, R. M., Langdon, P. G., and West, S. (2008). Bronze Age upland settlement decline in southwest England: Testing the climate change hypothesis. Journal of Archaeological Science 35: 87-98.

Barrett, J. H. (2003). Contact, Continuity, and Collapse: The Norse Colonization of the North Atlantic, Brepols, Turnhout, Belgium.

Bawden, G. (1995). Moche culture as political ideology. Latin American Antiquity 6: 255-273.

Benson, L. V. (2010). Who provided maize to Chaco Canyon after the mid-12th century drought? Journal of Archaeological Science 37: 621-629.

Benson, L. V., Cordell, L., Vincent, K., Taylor, H., Stein, J., Farmer, G. L., and Futa, K. (2003). Ancient maize from Chacoan great houses: Where was it grown? Proceedings of the National Academy of Sciences 100: 13111-13115.

Beramendi-Orosco, L. E., Gonzalez-Hernandez, G., Urrutia-Fucugauchi, J., Manzanilla, L. R., SolerArechalde, A. M., Goguitchaishvili, A., and Jarboe, N. (2009). High-resolution chronology for the Mesoamerican urban center of Teotihuacan derived from Bayesian statistics or radiocarbon and archaeological data. Quaternary Research 71: 99-107.

Blanton, R. E. (1990). Review of Tainter, J. A., The Collapse of Complex Societies. American Antiquity 55: $421-423$.

Bowersock, G. W. (1991). Review of Tainter, J. A., The Collapse of Complex Societies. Journal of Field Archaeology 18: 119-121.

Bryson, R. A., Lamb, H. H., and Donley, D. R. (1974). Drought and the decline of Mycenae. Antiquity 48 : $46-50$.

Buhaug, H. (2010). Climate not to blame for African civil wars. Proceedings of the National Academy of Sciences 107: 16477-16482.

Burke, M. B., Miguel, E., Satyanath, S., Dykema, J. A., and Lobell, D. B. (2009). Warming increases the risk of civil war in Africa. Proceedings of the National Academy of Sciences 106: 20670-20674.

Caldararo, N. (2004). Sustainability, Human Ecology, and the Collapse of Complex Societies: Economic Anthropology and a 21st Century Adaptation, Edward Mellen Press, Lewiston, NY.

Carpenter, R. (1966). Discontinuity in Greek Civilization, Cambridge University Press, Cambridge.

Carruthers, J. (2006). Mapungubwe: An historical and contemporary analysis of a World Heritage cultural landscape. Koedoe 49: 1-13.

Cook, E. R., Seager, R., Cane, M. A., and Stahle, D. W. (2007). North American drought: Reconstructions, causes and consequences. Earth Science Reviews 81: 93-134.

Cook, E. R., Seager, R., Heim, R. R., Vose, R. S., Herweijer, C., and Woodhouse, C. (2010). Megadroughts in North America: Placing the IPCC projections of hydroclimatic change in a longterm palaeoclimatic context. Journal of Quaternary Science 25: 48-61.

Cowgill, G. L. (2008). An update on Teotihuacan. Antiquity 82: 962-975.

Deger-Jalkotzy, S., and Zavadil, M. (eds.) (2003). LH IIIC Chronology and Synchronisms, Verlag der Österreichischen Akademie der Wissenschaften, Austrian Academy of Sciences Press, Vienna.

Demandt, A. (1984). Der Fall Roms: Die Aufösung des römischen Reiches im Urteil der Nachwelt, Beck, Munich.

Dickinson, O. T. (1974). 'Drought and the decline of Mycenae': Some comments. Antiquity 48: 228-230. Erdkamp, P. (ed.) (2007). A Companion to the Roman Army, Blackwell, Oxford.

Fagan, B. (2000). The Little Ice Age: How Climate Made History, 1300-1850, Basic Books, New York.

Fan, K.-W. (2010). Climatic change and dynastic cycles in Chinese history: A review. Climatic Change 101: $565-573$. 
Fischer, B., Genz, H., Jean, E., and Köroglu, K. (eds.) (2003). Identifying Changes: The Transition from Bronze to Iron Ages in Anatolia and Its Neighbouring Regions, Türk Eskiçag Bilimleri Enstitüsü, Istanbul.

Fuchs, C. (2003). Some implications of Pierre Bourdieu's works for a theory of social self-organization. European Journal of Social Theory 6: 387-408.

Gamble, L. H. (2005). Culture and climate: Reconsidering the effect of palaeoclimatic variability among southern Californian hunter-gather societies. World Archaeology 37: 92-108.

Gunn, J., and Adams, R. E. (1981). Climatic change, culture and civilization in North America. World Archaeology 13: 87-100.

Harmansah, O. (2011). Moving landscapes, making place: Cities, monuments and commemoration at Malizi/Melid. Journal of Mediterranean Archaeology 24: 55-83.

Hawkins, J. D. (1995). Karkamish and Karatepe: Neo-Hittite city-states in north Syria. In Sasson, J. (ed.), Civilizations of the Ancient Near East, Hendrickson, Peabody, MA, pp. 1295-1307.

Hawkins, J. D. (2002). Anatolia: The end of the Hittite empire and after. In Braun-Holzinger, E. A., and Matthäus, H. (eds.), Die nahöstlichen Kulturen und Griechenland an der Wende vom 2. zum 1. Jahrtausend v. Chr. Kontinuität und Wandel von Strukturen und Mechanismen kultureller Interaktion, Bibliopolis, Möhnesee, Germany, pp. 144-151.

Heather, P. (2005). The Fall of the Roman Empire: A New History, Pan Macmillan, London.

Huffman, T. N. (2008). Climate change during the Iron Age in the Shashe-Limpopo Basin, southern Africa. Journal of Archaeological Science 35: 2032-2047.

Huffman, T. N. (2009). Mapungubwe and Zimbabwe: The origin and spread of social complexity in southern Africa. Journal of Anthropological Archaeology 28: 37-54.

Janssen, M. A., Kohler, T. A., and Scheffer, M. (2003). Sunk-cost effects and vulnerability to collapse in ancient societies. Current Anthropology 44: 722-728.

Johnston, K. T., Breckenridge, A. J., and Hansen, B. C. (2001). Paleoecological evidence of an early Postclassic occupation in the southwestern Maya lowlands: Laguna las Pozas, Guatemala. Latin American Antiquity 12: 149-166.

Jones, T. L., Brown, G. M., Raab, L. M., McVickar, J. L., Spaulding, W. G., Kennett, D. J., York, A., and Walker, P. L. (2004). Environmental imperatives reconsidered: Demographic crises in western North America during the medieval climatic anomaly. In Raab, L. M., and Jones, T. L. (eds.), Prehistoric California: Archaeology and the Myth of Paradise, University of Utah Press, Salt Lake City, pp. 12-32.

Kagan, D. (ed.) (1992). The End of the Roman Empire, 3rd ed., D.C. Heath and Company, Lexington, MA.

Kantner, J. (2004). Ancient Puebloan Southwest, Cambridge University Press, Cambridge.

Kenoyer, J. M. (1991). The Indus Valley tradition of Pakistan and western India. Journal of World Prehistory 5: 331-385.

Kenoyer, J. M. (1998). Ancient Cities of the Indus Valley Civilization, Oxford University Press, Karachi, Pakistan.

Kerr, R. A. (1998). Sea-floor dust shows drought felled Akkadian empire. Science 279: 325-326.

Kim, N. C., and Kusimba, C. M. (2008). Pathways to social complexity and state formation in the southern Zambezian region. African Archaeology Review 25: 131-152.

Knapp, A. B. (2008). Prehistoric and Protohistoric Cyprus: Identity, Insularity and Connectivity, Oxford University Press, Oxford.

Larson, D. O., Neff, H., Graybill, D. A., Michaelson, J., and Ambos, E. (1996). Risk, climatic variability, and the study of southwestern prehistory: An evolutionary perspective. American Antiquity 61: 217-241.

Marcone, A. (2008). A long late antiquity? Considerations on a controversial periodization. Journal of Late Antiquity 1: 4-19.

Miles, R. (2010). Carthage Must be Destroyed: The Rise and Fall of an Ancient Civilization, Allen Lane, London.

Millar, F. (1968). Local cultures in the Roman Empire: Libyan, Punic and Latin in Roman Africa. Journal of Roman Studies 58: 126-134.

Miller, D. (1985). Ideology and the Harappan civilization. Journal of Anthropological Archaeology 4 : 34-71.

Millon, R. (1988). The last years of Teotihuacan dominance. In Yoffee, N., and Cowgill, G. L. (eds.), Collapse of Ancient States and Civilizations, University of Arizona Press, Tucson, pp. 102-164. 
Misra, V. N. (1984). Climate, a factor in the rise and fall of the Indus civilization: Evidence from Rajasthan and beyond. In Lal, B. B., and Gupta, S. P. (eds.), Frontiers of the Indus Civilization, Books and Books, Delhi, pp. 461-489.

Mitchell, P. (2002). The Archaeology of Southern Africa, Cambridge University Press, Cambridge.

Mughal, M. R. (1990). The decline of the Indus civilization and the Late Harappan period in the Indus Valley. Lahore Museum Journal 3: 1-22.

Myers, E. (1989). Review of Tainter, J. A., The Collapse of Complex Society [1988], Yoffee, N., and Cowgill G. L. (eds.), The Collapse of Ancient States and Civilizations [1988]. American Anthropologist 91: 1065-1066.

O'Connor, T. G., and Kiker, G. A. (2004). Collapse of the Mapungubwe society: Vulnerability of pastoralism to increasing aridity. Climatic Change 66: 49-66.

Page, S. E. (2005). Are we collapsing? A review of Jared Diamond's Collapse: How Societies Choose to Fail or Succeed. Journal of Economic Literature 43: 1049-1062.

Pauketat, T. R., and Emerson, T. E. (eds.) (1997). Cahokia: Domination and Ideology in the Mississippian World, University of Nebraska Press, Lincoln.

Peiser, B. (2003). Climate change and civilizational collapse. In Okonski, K. (ed.), Adapt or Die: The Science, Politics and Economics of Climate Change, Profile Books, London, pp. 191-204.

Pikirayi, I. (2001). The Zimbabwe Culture: Origins and Decline of Southern Zambezian States. AltaMira, Walnut Creek, CA.

Possehl, G. L. (2000). The drying up of the Sarasvati: Environmental disruption in South Asian prehistory. In Bawden, G., and Reycraft, R. M. (eds.), Environmental Disaster and the Archaeology of Human Response, Anthropological Papers No. 7, Maxwell Museum of Anthropology, Albuquerque, NM, pp. 63-74.

Possehl, G. L. (2002). The Indus Civilization: A Contemporary Perspective, AltaMira Press, Walnut Creek, CA.

Rehak, P., and Younger, J. G. (2001). Neopalatial, final palatial and postpalatial Crete. In Cullen, T. (ed.), Aegean Prehistory: A Review, Archaeological Institute of America, Boston, pp. 383-473.

Richard, S. (1987). Archaeological sources for the history of Palestine: The Early Bronze Age: The rise and collapse of urbanism. The Biblical Archaeologist 50: 22-43.

Rogers, A., and Hingley, R. (2010). Edward Gibbon and Francis Haverfield: The traditions of imperial decline. In Bradley, M. (ed.), Classics and Imperialism in the British Empire, Oxford University Press, Oxford, pp. 189-209.

Rule, J. B. (1989). Review of Tainter, J. A., The Collapse of Complex Societies [1988]. Population and Environment 11: 72-74.

Sanderson, S. K. (1999). Social Transformations: A General Theory of Historical Development, Rowman and Littlefield, Lanham, MD.

Sandweiss, D., and Quilter, J. (eds.) (2008). El niño, Catastrophism, and Culture Change in Ancient America, Dumbarton Oaks, Washington, DC, pp. 187-242.

Shinde, V., Deshpande, S. S., Osada, T., and Uno, T. (2006). Basic issues in Harappan archaeology: Some thoughts. Ancient Asia 1: 63-72.

Singh, G., Wasson, R. J., and Agrawal, D. P. (1990). Vegetational and seasonal climate changes since last full glacial in the Thar desert. Review of Palaeobotany and Palynology 64: 351-358.

Snooks, G. D. (1996). The Dynamic Society: Exploring the Sources of Global Change, Routledge, London.

Staubwasser, M., Sirocko, F., Grootes, P. M., and Segl, M. (2003). Climate change at the 4.2 ka BP termination of the Indus Valley civilization and Holocene south Asian monsoon variability. Geophysical Research Letters 30: 1425, doi:10.1029/2002GL016822.

Steadman, S. R., and McMahon, G. (eds.) (2011). The Oxford Handbook of Ancient Anatolia, Oxford University Press, New York.

Sutton, A. E., Dohn, J., Loyd, K., Tredennick, A., Bucini, G., Solorzano, A., Prihodko, L., and Hanan, N. P. (2010). Does warming increase the risk of civil war in Africa? Proceedings of the National Academy of Sciences 107: E102.

Swift, E. (2010). The End of the Western Roman Empire: An Archaeological Investigation, The History Press, Stroud.

Tainter, J. A. (2000). Problem solving: Complexity, history, sustainability. Population and Environment: A Journal of Interdisciplinary Studies 22: 3-41.

Tol, R. S., and Wagner, S. (2010). Climate change and violent conflict in Europe over the last millennium. Climatic Change 99: 65-79. 
Turchin, P. (2003). Historical Dynamics: Why States Rise and Fall, Princeton University Press, Princeton, NJ.

Turchin, P., and Hall, T. D. (2003). Spatial synchrony among and within world-systems: Insights from theoretical ecology. Journal of World Systems Research 9: 37-64.

Ward-Perkins, B. (2009). 407 and all that: Retrospective. Journal of Late Antiquity 2: 75-78.

Weiss, B. (1982). The decline of Late Bronze Age civilization as a possible response to climate change. Climate Change 4: 173-198.

Whitehouse, D. (1988). Review of Tainter, J. A., The Collapse of Complex Societies [1988]. Antiquity 62 : 798-799.

Whittaker, C. R. (2004). Rome and Its Frontiers: The Dynamics of Empire, Routledge, London.

Whittow, M. (2009). Early medieval Byzantium and the end of the ancient world. Journal of Agrarian Change 9: 134-153.

Williams, E. W. (1962). The end of an epoch. Greece and Rome 9: 109-125.

Yasuda, Y., and Shinde, V. (eds.) (2001). Monsoon and Civilization, Roli Books, New Delhi.

Yerkes, R.W. (1998). The Woodland and Mississippi traditions in the prehistory of midwestern North America. Journal of World Prehistory 2: 307-358.

Younger, J. G., and Rehak, P. (2008a). The material culture of neopalatial Crete. In Shelmerdine, C. W. (ed.), The Cambridge Companion to the Aegean Bronze Age, Cambridge University Press, Cambridge, pp. 140-164.

Younger, J. G., and Rehak, P. (2008b). Minoan culture: Religion, burial customs, and administration. In Shelmerdine, C. W. (ed.), The Cambridge Companion to the Aegean Bronze Age, Cambridge University Press, Cambridge, pp. 165-185. 